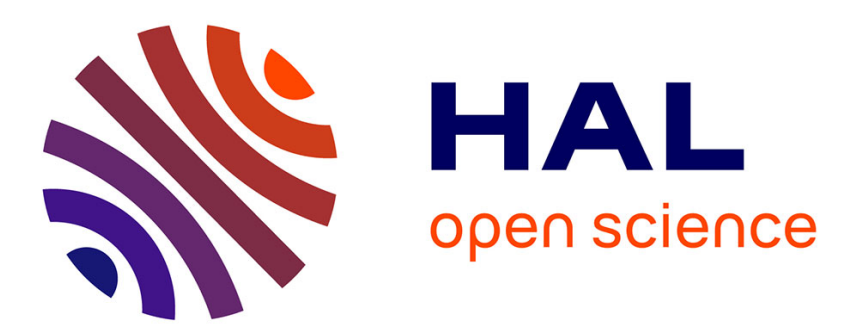

\title{
Effect of temperature variation in Agarophyton chilensis: contrasting the response of natural and farmed populations
}

Sara Usandizaga, Carolina Camus, José Luis Kappes, Marie-Laure Guillemin, Alejandro Buschmann

\section{To cite this version:}

Sara Usandizaga, Carolina Camus, José Luis Kappes, Marie-Laure Guillemin, Alejandro Buschmann. Effect of temperature variation in Agarophyton chilensis: contrasting the response of natural and farmed populations. Journal of Applied Phycology, 2019, pp.1-9. 10.1007/s10811-019-1757-6 . hal02148026

\section{HAL Id: hal-02148026 \\ https://hal.sorbonne-universite.fr/hal-02148026}

Submitted on 5 Jun 2019

HAL is a multi-disciplinary open access archive for the deposit and dissemination of scientific research documents, whether they are published or not. The documents may come from teaching and research institutions in France or abroad, or from public or private research centers.
L'archive ouverte pluridisciplinaire HAL, est destinée au dépôt et à la diffusion de documents scientifiques de niveau recherche, publiés ou non, émanant des établissements d'enseignement et de recherche français ou étrangers, des laboratoires publics ou privés. 
1 EFFECT OF TEMPERATURE VARIATION IN AGAROPHYTON CHILENSIS:

2 CONTRASTING THE RESPONSE OF NATURAL AND FARMED POPULATIONS

3 Sara Usandizaga

4 Programa de Doctorado en Ciencias, mención Conservación y Manejo de Recursos

5 Naturales, Centro i $\sim \operatorname{mar}$ and CeBiB, Universidad de Los Lagos, Camino Chinquihue Km 6,

6 Puerto Montt, Chile

7 Carolina Camus

8 Centro i mar and CeBiB, Universidad de Los Lagos, Camino Chinquihue Km 6, Puerto

9 Montt, Chile

10 José Luis Kappes

11 Centro i mar and CeBiB, Universidad de Los Lagos, Camino Chinquihue Km 6, Puerto

12 Montt, Chile

13 Marie-Laure Guillemin

14 Centro FONDAP de Investigación en Dinámica de Ecosistemas Marinos de Altas Latitudes

15 (IDEAL), Instituto de Ciencias Ambientales y Evolutivas, Facultad de Ciencias,

16 Universidad Austral de Chile, Valdivia, Chile.

17 CNRS, Sorbonne Université, Pontificia Universidad Catolica de Chile, Universidad Austral 18 de Chile, UMI Evolutionary Biology and Ecology of Algae, Station Biologique de Roscoff, 1929680 Roscoff, France.

20 Alejandro H. Buschmann ${ }^{2}$ 
21 Centro i mar and CeBiB, Universidad de Los Lagos, Camino Chinquihue Km 6, Puerto

22 Montt, Chile

$23{ }^{1}$ Date of submission and acceptance

$24 \quad 2$ Author for correspondence: Alejandro H. Buschmann, e-mail: abuschma@ulagos.cl, 25 phone: +56652322423

26 Running title: Agarophyton chilensis response to temperature variation

\section{Abstract}

28 During the domestication process, farmers influence the reproduction and care of organisms

29 to ensure a predictable supply of the resource of interest, causing changes in phenotypic

30 and genotypic character frequencies. In Chile, as a result of unconscious selection and

31 domestication process, farmed populations of the red alga Agarophyton chilensis have most

32 likely undergone a reduction in genetic diversity and a modification in life-history traits

33 compared to wild populations. In order to understand the implications that these processes

34 may have in A. chilensis, in this study we investigated how temperature variations $\left(10{ }^{\circ} \mathrm{C}\right.$,

$3515^{\circ} \mathrm{C}$ and $20^{\circ} \mathrm{C}$ ) affect growth and photosynthetic responses of natural and farmed

36 populations from three different localities along the Chilean coast. Natural population's

37 growth decreased at low and high temperature levels while all three farmed populations

38 respond in a very similar way to temperature variation. We propose that a possible outcome

39 of farming, in the A. chilensis vegetatively propagated crops, could have been the selection

40 of general-purpose-genotypes able to perform adequately across the range of temperature

41 tested in our experiment. Furthermore, our results showed that photosynthetic activity was

42 also affected by temperature treatments (e.g., different maximum maximal electron 
43 transport rate and quantum yield values depending on the population type and temperature).

44 In a context of climate change, A. chilensis farmed populations may be better able to cope

45 with impacts of anthropogenic activities than natural populations due to the buffer effect of

46 their general-purpose-genotypes, tolerant to a wide range of conditions.

47 Key index words: abiotic factor, domestication, management, general-purpose-genotypes, 48 photosynthesis, origin, seaweed, selection.

49 Abbreviations: ETR $\max _{\text {, }}$ maximal electron transport rate; $F_{v} / F_{m}$, maximal quantum yield; $E k$,

50 irradiance of saturation of ETR; NPQ $\max$, maximal non-photochemical quenching; PAR,

51 photosynthetically active radiation; PSII, photosystem II; RLC, rapid light curves.

\section{Introduction}

53 Domestication is considered a long and complex process during which domesticators

54 influence the reproduction and care of domesticated species to guarantee predictable supply

55 of resources presenting selected traits of interest for human use (Zeder, 2015). This

56 selection process generates changes in phenotypic and genotypic character frequencies of

57 cultivated populations (Zohary, 1984). Even if domestication of marine species is much

58 more recent than the one of terrestrial animals and plants (Duarte et al. 2007), strong

59 evidence for domestication has been found in a few cultivated seaweeds (Valero et al.

60 2017). As for terrestrial plants (Meyer et al. 2012), some domesticated seaweeds are

61 characterized by a shift in their reproductive strategy (e.g., changes from sexual

62 reproduction to vegetative propagation) between natural and farmed populations (Valero et

63 al. 2017). This shift in reproductive strategy has been demonstrated for Agarophyton

64 (referred as Gracilaria in Guillemin et al. 2008) and is probably also present in 
65 Kappaphycus (Ask and Azanza 2002). Asexual propagation enables farmers to selectively

66 multiply superior genotypes and maintain desired phenotypes through vegetative

67 propagation (Valero et al. 2017).

68 In Chile, intensive seaweed farming is limited to the domesticated red alga Agarophyton

69 chilensis used mainly for agar extraction (Buschmann et al. 2017). Even if the

70 domestication process of this species has begun only a few decades ago, the almost

71 complete predominance of diploid individuals in farms demonstrate that farming practices

72 had significantly modified life-history traits as compared to wild populations (Guillemin et

73 al. 2008). Moreover, recent investigations have demonstrated that this red alga colonized

74 the Chilean coast from New Zealand, likely at the end of the Last Glacial Maximum

75 (Guillemin et al. 2014). The lower genetic diversity of the Chilean populations, when

76 compared to the ones from New Zealand, is indeed consistent with a genetic bottleneck

77 resulting from a transpacific range extension and was probably reinforced by the over-

78 exploitation of natural Chilean populations during the 90's (Guillemin et al. 2014). In

79 Chile, active transport and exchange of inoculums of A. chilensis between coastal

80 communities of fishermen for cultivation purposes have contributed to the artificial

81 expansion of the species distribution. Nowadays, natural populations are distributed

82 between $30^{\circ} \mathrm{S}$ to $45^{\circ} \mathrm{S}$ while farming extends further north, up to Antofagasta, $17^{\circ} \mathrm{S}$ (Bird et

83 al. 1986, Guillemin et al. 2008). Human activities have also leaded to a loss of genotypic

84 diversity in farmed populations that could be partially linked to involuntary selection of

85 faster growing thalli, during the first steps of the domestication process (Guillemin et al.

86 2008, Guillemin et al. 2013, Valero et al. 2017). 
87 Reduced genetic diversity can severely affect the ability of populations to resist pests and

88 pathogens and limit the scope for future genetic improvement in domesticated crops

89 (Robinson et al. 2013). Besides, it has been reported that a reduction in genetic diversity

90 could lead to lower growth and resilience in highly stressful and/or variable environment

91 (Simms 2000). However, to date, few studies have focused on the potential

92 ecophysiological differences between natural and farmed populations of A. chilensis.

93 Gallegos-Sánchez et al. (2018), detected a significant and negative effect of low salinity

94 conditions on thalli sampled from both natural and farmed A. chilensis populations but with

95 farmed population's thalli being less affected than the natural ones. Results suggested that

96 farmed populations might be more tolerant to salt stress than wild ones in this species and

97 the authors proposed that this difference between population types could be due to previous

98 selective process carried out by farmers.

99 Considering the possible consequences of unconscious selection (as defined in Zohary

100 2004) and domestication on Agarophyton chilensis, we propose that natural populations

101 will be less sensitive to temperature variations than farmed populations. Genotypic

102 diversity has been shown to be higher in natural than farmed A. chilensis Chilean

103 populations and we propose that the farms will show less effective mechanisms of

104 acclimation (e.g., enhancing of photosynthetic performance) than the one observed in

105 natural populations when confronted with temperature considered as high in their natural

106 environment (i.e., water of the southern coast of Chile do not generally reach $20^{\circ} \mathrm{C}$;

107 Westermeier et al. 1993). The aim of the present study was to assess the effect of

108 temperature on growth and photosynthetic responses of both natural and farmed stands of

109 A. chilensis and tetrasporophyte thalli sampled from three sites along the Chilean coast 
were followed during one month in controlled laboratory conditions at $10^{\circ} \mathrm{C}, 15^{\circ} \mathrm{C}$ and

$11120^{\circ} \mathrm{C}$.

\section{Materials and methods}

113 Study sites and life cycle phase determination of the sampled thalli

114 A total of 600 individuals were sampled from 3 natural and 3 farmed populations (i.e., 100

115 individuals in each population) during a spring season. One farmed and one natural

116 population were sampled from three sites: Concepción, Maullín and Ancud (Fig.1). The

117 distinction between natural and farmed populations was first based on whether

118 Agarophyton chilensis thalli were actively planted or not by farmers. As previously

119 reported for the species (Guillemin et al. 2008), thalli were attached to small rocks and

120 pebbles by a holdfast in the three natural A. chilensis beds while unattached thalli were

121 found embedded in the sandy bottom in the three farmed stands. In each site, natural and

122 farmed populations were separated by $1 \mathrm{~km}$ approximately. In natural beds, individuals

123 sampled correspond to distinct holdfasts (i.e., distinct genotypes produced by sexual

124 reproduction and spore settlement). In farms, to avoid sampling fragments of the same

125 asexually propagated genotype, sampled thalli were separated by at least by $2 \mathrm{~m}$. All the

126 collected thalli were transported in isolated boxes to the CEACIMA hatchery (Centro de

127 Investigación de Acuicultura y Ciencias del Mar, Universidad de Los Lagos) located in the

128 Metri Bay $\left(41^{\circ} 36^{\prime} \mathrm{S}, 72^{\circ} 43^{\prime} \mathrm{W}\right)$. Once in the hatchery, each thallus was cleaned with fresh

129 water and all epiphytes were removed by hand. Thalli were individually marked with a

130 numbered tag and maintained in $400 \mathrm{~L}$ tanks at $12^{\circ} \mathrm{C}$ with constant aeration, $12 \mathrm{~L}: 12 \mathrm{D}$

131 photoperiod, $20 \mu \mathrm{mol}$ electron $\mathrm{m}^{-2} \mathrm{~s}^{-1}$ photon flux and weekly filtered seawater exchange. 
132 Collected thalli were observed under stereoscope microscope (Stemi DV4, Zeiss, Jena,

133 Germany) to determine phase (i.e., diploid tetrasporophytes or haploid gametophytes) of

134 mature individuals. For vegetative individuals, a 3-cm fragment of tissue was excised from

135 each thallus, placed into plastic bags with silica gel for rapid dehydration. The sex markers

136 available for $A$. chilensis were amplified following Guillemin et al. (2012) and the

137 amplification products were visualized in $1.5 \%$ agarose gel (w/v) after adding $2 \mu 1$ of

138 GelRed ${ }^{\mathrm{TM}}$ (Biotium, Fremont, USA). Results were used to determine sex and phase of

139 vegetative individuals. In order to prevent experimental bias due to ecophysiological

140 variability between life cycle phases (Guillemin et al. 2013), only diploid tetrasporophytes

141 were selected for our experiments.

142 Experimental design

143 The experimental design consisted of 90 2-L Erlenmeyer flasks (i.e., 6 populations of origin

144 of thalli $\times 3$ temperature treatments $\times 5$ replicates per population per temperature treatment)

145 arranged in 15 60-L plastic water tanks fitted with temperature control systems. Three

146 temperature treatments were used: $10^{\circ} \mathrm{C}, 15^{\circ} \mathrm{C}$ and $20^{\circ} \mathrm{C}$. These temperatures were chosen

147 since they roughly represent the temperature range encountered in the field by the study

148 species. Temperature conditions varied widely within sites were A. chilensis is found and

149 between regions populated by the species along the Chilean coasts with values between 9

$150{ }^{\circ} \mathrm{C}$ and $16{ }^{\circ} \mathrm{C}$ recorded in Maullín (Westermeier et al. 1993) and between $10{ }^{\circ} \mathrm{C}$ and $20^{\circ} \mathrm{C}$

151 in areas further north such as Concepción, Coquimbo and Antofagasta (Santelices and

152 Ugarte 1990). In each 60-L plastic water tanks, one 50W automatic heater (Whale VK-

153 1000, Regent) and one stainless steel thermometer (Hagen, Phelan) were used to maintain

154 constant temperature. For each population under study, five replicates (i.e., five 2-L flasks) 
were followed per temperature treatment and eight thalli $(5 \mathrm{~cm}$ length each), selected randomly from distinct tetrasporophytes, were placed in each 2-L flask. Thalli were selected without replacement from a pool of 40 tetrasporophytes, available for each population of origin (see above). Once a week, thalli were transferred to clean 2-L flasks with fresh Provasoli culture media (McLachlan 1973). After one week of acclimation at $12^{\circ} \mathrm{C}$, the laboratory experiment was run during 30 days. All Erlenmeyer flasks were under constant conditions of aeration, photoperiod (12 h light: $12 \mathrm{~h}$ dark) and photon flux (20 $\mu \mathrm{mol}$ electron $\left.\mathrm{m}^{-2} \mathrm{~s}^{-1}\right)$.

\section{Growth}

Fresh weight of each thallus was assessed weekly on an analytical balance (Sartorius TE 313 DS, Germany) and the specific growth rate (SGR) was calculated as the percentage of wet weight gain per day according to the formula: $\mathrm{SGR}=\left[\ln \left(\mathrm{Wf} \cdot \mathrm{Wi}^{-1}\right) /(\mathrm{tf}-\mathrm{ti})\right] \mathrm{x} 100$; where $\mathrm{Wi}=$ initial fresh weight, $\mathrm{Wf}=$ final fresh weight, and $\mathrm{t}=$ time (days). Initial fresh weight in the 2 -L flasks was of $0.12 \pm 0.06 \mathrm{~g}$, some variation in fresh weight exist between each 2-L flask at the beginning of the experiment since calibration of algal material was based on thallus length (see above).

\section{Physiological variables}

Thallus pieces were collected at the end of the experiment to measure rapid light curves (RLC). As an indicator of quantum efficiency and photoinhibition, we used, $F_{\mathrm{v}} / F_{\mathrm{m}}$, which was determined after incubation of 20 min of the thalli in darkness (Schreiber et al. 1995) with a Junior PAM (Walz GmbH, Effeltrich, Germany). The electron transport rate (ETR, $\mu \mathrm{mol}$ electrons $\cdot \mathrm{m}^{-2} \cdot \mathrm{s}^{-1}$ ) was determined after $20 \mathrm{~s}$ exposure in 12 increasing intensities of 
177 PAR (up to $1500 \mu \mathrm{mol}$ photon $\cdot \mathrm{m}^{-2} \cdot \mathrm{s}^{-1}$ ) provided by a blue light of the Junior PAM device

178 (Schreiber et al. 1995). ETR was calculated according to Schreiber et al. (1995) as follows:

$179 \quad \mathrm{ETR}=\Delta \mathrm{F} / \mathrm{F}^{\prime} \mathrm{m} \cdot E \cdot A \cdot F_{\mathrm{II}}\left(\mu \mathrm{mol}\right.$ electrons $\left.\cdot \mathrm{m}^{-2} \cdot \mathrm{s}^{-1}\right)$

180 Where $\Delta \mathrm{F} / \mathrm{F}^{\prime} \mathrm{m}$ is the effective quantum yield, $E$ is the incident PAR (photosynthetically

181 active radiation) irradiance expressed in $\mu \mathrm{mol}$ photons $\mathrm{m}^{-2} \mathrm{~s}^{-1}, A$ is the thallus absorptance

182 and $F_{\mathrm{II}}$ is the fraction of chlorophyll related to photosystem II (PSII, 400-700m), being 0.15

183 in red seaweed (Grzymski et al. 1997). As an estimator of photosynthetic efficiency, the

184 initial slope of ETR $\left(\alpha_{\mathrm{ETR}}\right)$ and maximum ETR $\left(\mathrm{ETR}_{\max }\right)$ were obtained from the tangential

185 function reported by Eilers and Peeters (1988) and the irradiance saturation $\left(E k_{\mathrm{ETR}}\right)$ was

186 calculated from the intercept between these two parameters. Representing potential thalli

187 photoprotective mechanism, non-photochemical quenching (NPQ) was measured according

188 to Schreiber et al. (1995). The maximal non-photochemical quenching (NPQ $\max )$ was

189 calculated from the tangential function of NPQ versus irradiance function according to

190 Eilers and Peeters (1988).

$191 \quad$ Statistical treatment

192 All analyses were performed in R (3.2.4 version) (Cayuela 2011). Assumptions of

193 homogeneity of variances and normal distribution were tested using Levene`s test and

194 Shapiro-Wilk, respectively. When non-normal residuals and heteroscedasticity were

195 detected, the data were transformed using logarithm (for $E k$ and SGR) or Box-cox (for

$\left.196 F_{\mathrm{v}} / F_{\mathrm{m}}\right)$. The experimental design fitted a three-way ANOVA with treatment (temperature:

$19710^{\circ} \mathrm{C}, 15^{\circ} \mathrm{C}$ and $20^{\circ} \mathrm{C}$ ), site of origin (Concepción, Maullín and Ancud) and population type 
198 (natural or farmed) considered as fixed factors. Statistical differences between groups were 199 analyzed using comparisons of means (Tukey's HSD). Significances were set at $\mathrm{p}<0.05$.

200

201

202

203

204

205

206

207

208

209

210

211

212

213

214

\section{Results}

Significant differences were detected in Agarophyton chilensis specific growth rate (SGR) after 30 days of experimentation between temperature treatments $\left(\mathrm{F}_{(2,72)}=15.46 ; \mathrm{P}<\right.$ $0.0001)$, between population types $\left(\mathrm{F}_{(1,72)}=4.93 ; \mathrm{P}=0.03\right)$ and a significant interaction was also detected between population type and site of origin $\left(\mathrm{F}_{(2,72)}=5.00 ; \mathrm{P}=0.009\right)$. In Maullín and Ancud, no significant differences between temperature treatments were detected for farmed thalli (Fig.2C and E), while farmed thalli from Concepción showed a slightly but significantly lower SGR at $20^{\circ} \mathrm{C}$ than at $15^{\circ} \mathrm{C}(7.26 \pm 1.48$ and $9.45 \pm 1.92 \mathrm{~g} \cdot$ day $^{-1}$, respectively; Fig.2A). In addition, differences among Concepción farmed and natural populations were observed (Tukey test; $\mathrm{P}<0.05$, see Figure $2 \mathrm{~A}$ and $\mathrm{B}$ ). In contrast, SGR was significantly higher at $15^{\circ} \mathrm{C}$ for thalli sampled in natural $A$. chilensis stands, whatever the site under study $\left(\mathrm{SGR}\right.$ at $15^{\circ} \mathrm{C}: 7.49 \pm 2.07 \mathrm{~g} \cdot$ day $^{-1}$ in Concepción, $8.81 \pm 2.60 \mathrm{~g} \cdot$ day $^{-}$ ${ }^{1}$ in Maullín and $8.67 \pm 0.84 \mathrm{~g} \cdot$ day $^{-1}$ in Ancud; Fig. 2B, D and F). Finally, the growth rate did not decrease significantly (Tukey test; $\mathrm{P}<0.05)$ at the lower $\left(10^{\circ} \mathrm{C}\right)$ and the higher $(20$ ${ }^{\circ} \mathrm{C}$ ) temperature tested for Maullin and Ancud populations (Fig. 2 C, D, E and F).

Regarding the photosynthetic responses, significant effect of temperature treatments were detected for all parameters measured: the optimal quantum yield of fluorescence $\left(F_{v} / F_{m}\right)$, the maximal electron transport rate $\left(\mathrm{ETR}_{\max }\right)$, the saturation irradiance $(E k)$ and the maximal non-photochemical quenching $\left(\mathrm{NPQ}_{\max }\right)$ (see Table 1). Interactions between temperature treatment and population type were also observed for ETR $\max$ and $E k$ (Table 1). Values of 
221 Concepción and grown at $20^{\circ} \mathrm{C}$ than for thalli sampled in the farmed population of Ancud 222 and grown at $10^{\circ} \mathrm{C}\left(18.63 \pm 12.76\right.$ and $1.44 \pm 0.37 \mu \mathrm{mol}$ electrons $\cdot \mathrm{m}^{-2} \cdot \mathrm{s}^{-1}, 442.97 \pm$

$223 \quad 306.60$ and $31.86 \pm 4.78 \mu \mathrm{mol}$ photons $\cdot \mathrm{m}^{-2} \cdot \mathrm{s}^{-1}$, for ETR $\mathrm{max}_{\max }$ and $E k$, respectively; Tukey's

224 HSD tests; $\mathrm{p}<0.05$; Table 2). Significant interactions between temperature treatment, 225 population type and site of origin were observed for $F_{v} / F_{m}$ and NPQ $\max$ (Table 1$)$. In

226 Maullín at $15^{\circ} \mathrm{C}$, values of $\mathrm{NPQ}_{\max }$ were significantly higher for thalli sampled in the

227 farmed bed than the natural population (Tukey’s HSD tests; $\mathrm{p}<0.05$; Table 2).

\section{Discussion}

229 The present study confirms that natural and farmed Agarophyton chilensis populations 230 respond differentially to temperature variations. Indeed, contrarily to our expectations, our 231 results indicate that farmed populations are less sensitive to temperature variations than 232 natural ones (i.e., thalli growth rate are mostly similar at $10^{\circ} \mathrm{C}, 15^{\circ} \mathrm{C}$ and $20^{\circ} \mathrm{C}$ for farms 233 while thalli from natural populations have a higher growth rate at $15^{\circ} \mathrm{C}$ ). In Chile, farmed 234 population has been under unconscious human selection pressure for, at least, three decades 235 and we propose that a possible outcome could have been the selection of general-purpose236 genotypes (as in Baker 1974) in these vegetatively propagated crops. Our results also 237 showed that photosynthetic activity was affected by temperature treatments (e.g., different 238 maximum maximal electron transport rate and quantum yield values depending on the 239 population type and temperature).

240 Regardless of the origin of the natural population under study, our experiment shows that 241 thalli specific growth rate (SGR) was higher at $15^{\circ} \mathrm{C}$ than at lower (i.e., $10^{\circ} \mathrm{C}$ ) or higher 242 (i.e., $20^{\circ} \mathrm{C}$ ) temperatures. Even if SGR tended to be much more homogeneous for farmed 
243 thalli at all temperatures, one slight difference was observed for the farmed thalli from

244 Concepción that show significantly less growth at $20^{\circ} \mathrm{C}$. Supporting our results, a study

245 realized by Santelices and Ugarte (1990) on A. chilensis (as Gracilaria chilensis) natural

246 populations from Maullín, also revealed better growth rates at $15^{\circ} \mathrm{C}$ than at $10^{\circ} \mathrm{C}$ or $20^{\circ} \mathrm{C}$.

247 Most temperate species of the genus Agarophyton has been shown to grow faster in

248 temperature ranging between $15^{\circ}$ and $20^{\circ} \mathrm{C}$ (McLachlan and Bird 1984). A study performed

249 in Gracilaria gracilis (as G. verrucosa) reported a slow growth rate at $10^{\circ} \mathrm{C}$ and high

250 mortality after a 14 days' heat-wave in Saldanha Bay, South Africa (Engledow and Bolton

251 1992). A. chilensis, is a temperate-water species with a distribution limited to southern part

252 of the Pacific (Bird et al. 1986, Guillemin et al. 2008) and it is possible that the species

253 present a metabolism with limited temperature tolerance.

254 Although farming has begun only a few decades ago (i.e., during the 80's) in Chile, the 255 predominant mechanism for stock propagation by cuttings used in Agarophyton chilensis

256 farms has already significantly decreased their genotypic diversity when compared with

257 wild populations (Guillemin et al. 2008). There is an overall agreement that genetically

258 more variable populations may be associated with higher resilience, increased productivity

259 and population growth rate as compared with less variable populations (Forsman 2014).

260 However, contrasting with our expectations, farmed thalli in our experiment clearly show a

261 strong ability to grow in contrasting environmental conditions, including the quite

262 "extreme" temperature of $20^{\circ} \mathrm{C}$ tested. In the same way, Gallegos-Sanchez et al. (2018)

263 concluded that A. chilensis farmed populations may be less sensitive to salt stress and able

264 to grow in a greater range of salinity than natural populations. One possible explanation for

265 these results is that farmed populations of A. chilensis are composed mostly of general- 
purpose genotypes, able to grow in highly stressful and/or variable environments. Generalpurpose-genotypes are sometime also referred as 'Jack-of-all-trades, master of none' since they are described as versatile genotypes that are able to perform adequately across a range of environments but are not superior in any of them. These general-purpose-genotypes can confer a species or population a broad tolerance to environmental changes and are often associated with species invasion (Baker 1974, Richards et al. 2006). In Chile, farms have been developed using material growing embedded in muddy estuaries and sandy bays. These habitats are typically highly heterogeneous and present strong seasonal variations in temperature and salinity (Westermeier et al. 1993, Buschmann et al. 1995). It have been demonstrated that intraspecific competition for resources utilization in clonal individuals living in habitats characterized by fluctuating environmental conditions could lead to positive selection of general-purpose-genotypes (Arnaud-Haond et al. 2012). In benthic algae, temperature variations affect photosynthetic metabolism (Davison 1991) determining, for example, seasonal distribution (De Nicola 1996). However, habitats characterized by strong spatial and temporal variations of abiotic factors, request constant adjustment of photosynthetic processes in species populating them (Ensminger et al. 2001). In our study, the highest values of ETR $\max$ and $E k$ were observed in the A. chilensis farmed population from Concepción grown at $20^{\circ} \mathrm{C}$. These results suggest that the effect of high temperatures on photosynthetic metabolism of this farmed population could be mild. Driven by seasonal changes in river discharge, precipitation, and coastal upwelling, high variability in abiotic conditions (e.g., temperature, salinity and turbidity; Saldías et al. 2016) has been observed in the river mouths were A. chilensis thalli are planted in Concepción. These characteristics could be associated to distinctive heat susceptibility of the photosynthetic metabolism of the A. chilensis thalli growing in Concepción farms. In 
291

292

293

294

295

296

297

298

299

300

301

302

303

304

305

306

307

308

309

310

311

312

our experiment, the response of the maximum quantum yield $\left(F_{\mathrm{v}} / F_{\mathrm{m}}\right)$ to temperature was quite variable. The lowest value of $F_{\mathrm{v}} / F_{\mathrm{m}}$ (indicating photoinhibition) was observed at intermediate temperature $\left(15^{\circ} \mathrm{C}\right)$ in the farm of Maullín. In plants, it is well known that limitation of electron transport that reduces the ability of plants to use light result in an excess light energy that may cause photoinhibition due to damage to the PSII apparatus (Moll and Steinback 1986). However, short-term response of photosynthesis to temperature cannot easily be used to infer the long-term response of algal growth (Wienke and Dieck 1989). Indeed, despite the possible signal of photoinhibition detected at $15^{\circ} \mathrm{C}$, no limited growth could be observed in these Agarophyton chilensis thalli.

Populations of Agarophyton chilensis from different sites in Chile have been reported to present ecological differences, potentially linked to local adaptation in response to specific abiotic and biotic environmental characteristics (Santelices and Ugarte 1990, Usandizaga et al. 2018). The success of Agarophyton farming depends in part on the origin of the initial inoculum since differences in thallus morphology, agar yield and gel strength and susceptibility to epiphytes exist among regions and populations. Indeed, it have been suggested that random transplantation between distinct habitats could lead to cultivation failure (Santelices and Ugarte 1990). However, in our experiment, even if we included sampling sites located more than $700 \mathrm{~km}$ apart, no major effect of the site of origin were detected on growth or photosynthesis. A possible explanation for this discrepancy is that continuous transplantations and exchanges during the last decades have leaded to the homogenization of the genetic diversity among the whole Chilean coast. However, this hypothesis is not in accordance with population genetic studies showing the presence of clear genetic divergence between regions in Chile (Guillemin et al. 2008 and 2014). Studies

313 focused on the effect of other stressors (e.g., nutrient supply, salinity, irradiance) and the 
314 cumulative effects of various of these stressors on the physiological responses of distinct

315 genotypes is now needed in order to better explore the resistance of $A$. chilensis populations

316 to stress.

\section{Conclusion}

Agarophyton chilensis tolerance of a wide range of abiotic conditions has been proposed as

one of the main reasons of the species successful expansion in the Pacific and establishment

321 in a wide array of habitats (Santelices and Ugarte 1990, Chow et al. 2001). These

322 successful extension waves have probably also been facilitated by intrinsic characteristics

323 of the species, such as its capacity to shift between sexual and asexual reproduction

324 (Guillemin et al. 2014). We suggest that the possible selection for general-purpose325 genotypes in the asexually reproducing farmed populations may help modulating the 326 impact of environmental variation on population dynamics (Reed et al. 2010) and Chilean

327 Agarophyton crop to better cope with impacts of climate change and direct anthropogenic

328 activities. Nevertheless, implementation of breeding strategy and cultivar selection for 329 mariculture systems improvement has not yet begun in Chile and development of long-term 330 management plans for the sustainable exploitation of A. chilensis populations is dearly 331 needed.

\section{Acknowledgements}

333 This research was supported by a doctoral fellow from Universidad de Los Lagos 334 (Chile) to SU, CeBiB (CONICYT, FB-0001) to AHB and CC and Fondecyt N¹150987 335 and $\mathrm{N}^{\circ} 1170541$ (CONICYT) to AHB and MLG, respectively. Additional support was 336 provided by the grant "Término de Tesis" awarded by Universidad de Los Lagos. The 
337 authors are grateful for the help in the field of R. Altamirano and S. V. Pereda for the

338 revision of this manuscript. We also wish to thank two anonymous referees who greatly

339 improved the manuscript with constructive suggestions. The authors declare no conflict

340 of interest.

341

342 References

343 Arnaud-Haond S, Duarte C, Diaz-Almela E, Marbà N, Sintes T, Serrão (2012) Implications

344 of extreme life span in clonal organisms: millenary clones in meadows of the threatened

345 seagrass Posidonia oceanica. PloS one 7:e30454.

346 Ask EI, Azanza RV (2002) Advances in cultivation technology of commercial

347 eucheumatoid species: a review with suggestions for future research. Aquaculture 206:257-

348277.

349 Baker HG (1974) The evolution of weeds. Annu Rev Ecol Syst 5:1-24.

350 Bird CJ, McLachan J, Oliveira EC (1986) Gracilaria chilensis sp. nov; (Rhodophyta,

351 Gigartinales), from Pacific South America. Can J Bot 64:2928-2934.

352 Buschmann AH, Westermeier R, Retamales C (1995) Cultivation of Gracilaria in the sea-

353 bottom in southern Chile: a review. J Appl Phycol 7:291-301.

354 Buschmann AH, Camus C, Infante J, Neori A, Israel A, Hernández-González MC, Pereda

355 SV, Gomez-Pinchetti JL, Golberg A, Tadmor-Shalex N, Critchley AT (2017) Seaweed

356 production: overview of the global state of exploitation, farming and emerging research

357 activity. Eur J Phycol 52:391-406.

358 Cayuela L (2011) Modelos lineales: Regresión, ANOVA y ANCOVA. Universidad Rey

359 Juan Carlos, Madrid. 
361 chilensis (Rhodophyta: Gracilariaceae) as a biofilter in the depuration of effluents from

362 tank cultures of fish, oysters, and sea urchins. J World Aquac Soc 32:215-220.

363 Davison IR (1991) Environmental effects on algal photosynthesis: temperature. J Phycol $364 \quad 27: 2-8$.

365 De Nicola DM (1996) Periphyton responses to temperature at different ecological levels. 366 In: Stevenson RJ, Bothwell ML, Lowe RL (eds) Algal ecology: freshwater benthic 367 ecosystems. Academic Press, San Diego, pp 149-181.

368 Duarte CM, Marbá N, Holmer M (2007) Rapid domestication of marine species. Science $369316: 382$.

370 Eilers PHC, Peeters JCH (1988) A model for the relationship between light intensity and 371 the rate of photosynthesis in phytoplankton. Ecol Model 42:199-215.

372 Engledow HR, Bolton JJ (1992) Environmental tolerances in culture and agar content of 373 Gracilaria verrucosa (Hudson) Papenfuss (Rhodophyta, Gigartinales) from Saldanha Bay. 374 S Afr J Bot 58:263-267.

375 Ensminger I, Xyländer M, Hagen C, Braune W (2001) Strategies providing success in a 376 variable habitat: III. Dynamic control of photosynthesis in Cladophora glomerata. Plant 377 Cell Environ 24:769-779.

378 Forsman A (2014) Rethinking phenotypic plasticity and its consequences for individuals, 379 populations and species. Heredity 115:1-9.

380 Gallegos-Sánchez CF, Beltrán J, Flores V, González AV, Santelices B (2018) Testing the 381 effects of heterozygosity on growth rate plasticity in the seaweed Gracilaria chilensis 382 (Rhodophyta). Ecol Evol 8:5741-5751. 
384 the bio-optical properties of brown, red and green macroalgae. J Phycol 33:408-414.

385 Guillemin M-L, Faugeron S, Destombe C, Viard F, Correa JA, Valero M (2008) Genetic

386 variation in wild and cultivated population the haploid-diploid red alga Gracilaria

387 chilensis: how farming practices favour asexual reproduction and heterozygosity. Evolution $388 \quad 62: 1500-1519$.

389 Guillemin M-L, Huanel OR, Martínez EA (2012) Characterization of genetic markers

390 linked to sex determination in the haploid-diploid red alga Gracilaria chilensis. J Phycol

$391 \quad 48: 365-372$.

392 Guillemin M-L, Sepúlveda RD, Correa, JA, Destombe C (2013) Differential ecological 393 responses to environmental stress in the life history phases of the isomorphic red alga 394 Gracilaria chilensis (Rhodophyta). J Appl Phycol 25:215-224.

395 Guillemin M-L, Valenzuela P, Gaitán-Espitia JD, Destombe C (2014) Evidence of 396 reproductive cost in the triphasic life history of the red alga Gracilaria chilensis 397 (Gracilariales, Rhodophyta). J Appl Phycol 26:569-575.

398 McLachlan J (1973) Growth media-marine. In: Stein JR (ed) Handbook of Phycological 399 Methods. Cambridge University Press, Cambridge, pp 25-52.

400 McLachlan J, Bird CJ (1984) Geographical and experimental assessment of the distribution 401 of species of Gracilaria in relation to temperature. Helgolander Meeresun 38:319-334.

402 Meyer RS, Duval AE, Jensen HR (2012) Patterns and processes in crop domestication: an 403 historical review and quantitative analysis of 203 global food crops. New Phytol 196:29-48. 
404 Moll BA, Steinback KE (1986) Chilling sensitivity in Oryza sativa: the role of protein 405 phosphorylation in protection against photounhibition. Plant Physiol 80:420-423.

406 Reed TE, Waples RS, Schindler DE, Hard JJ, Kinnison MT (2010) Phenotypic plasticity

407 and population viability: the importance of environmental predictability. Proc R Soc B $408 \quad 277: 3391-3400$.

409 Richards CL, Bossdorf O, Muth NZ, Gurevitch J, Pigliucci M (2006) Jack of all trades, 410 master of some? On the role of phenotypic plasticity in plant invasions. Ecol Lett 9:981411993.

412 Robinson N, Winberg P, Kirkendale L (2013) Genetic improvement of macroalgae: status 413 to date and needs for the future. J. Appl Phycol 25:703-716.

414 Saldías GS, Largier JL, Mendes R, Pérez-Santos I, Vargas CA, Sobarzo M (2016) Satellite-

415 measured interannual variability of turbid river plumes off central-southern Chile: spatial

416 patterns and the influence of climate variability. Prog Oceanogr 146:212-222.

417 Santelices B, Ugarte R (1990) Ecological differences among Chilean population of 418 commercial Gracilaria. J Appl Phycol 2:17-26.

419 Schreiber U, Endo T, Mi H, Asada K (1995) Quenching analysis of chlorophyll

420 fluorescence by the saturation pulse method: particular aspects relating to the study of 421 eukaryotic algae and cyanobacteria. Plant Cell Physiol 36:873-882.

422 Simms EL (2000) Defining tolerance as a norm of reaction. Evol Ecol 14:563-570. 
423 Usandizaga S, Camus C, Kappes JL, Guillemin M-L, Buschmann AH (2018) Nutrients, but 424 not genetic diversity, affect Gracilaria chilensis (Rhodophyta) farming productivity and 425 physiological responses. J Phycol 54:860-869.

426 Valero M, Guillemin M-L, Destombe C, Jacquemin B, Gachon C, Badis Y, Buschmann 427 AH, Camus C, Faugeron S (2017) Perspectives on domestication research for sustainable 428 seaweed aquaculture. Perspect Phycol 4:33-46.

429 Westermeier R, Gómez I, Rivera P (1993) Suspended farming of Gracilaria chilensis

430 (Rhodophyta, Gigartinales) at Cariquilda river, Maullín, Chile. Aquaculture 113:215-229.

431 Wienke C, Dieck I (1989) Temperature requirements for growth and temperature tolerance 432 of macroalgae endemic to the Antarctic region. Mar Ecol Prog Ser 54:189-197.

433 Zeder MA (2015) Core questions in domestication research. P Natl Acad Sci 11:31914343198.

435 Zohary D (1984) Modes of evolution in plants under domestication. In: Grant W F (ed)

436 Plant Biosystematics. Academic Press Canada, Montreal, pp 579-586.

437 Zohary D (2004) Unconscious selection and the evolution of domesticated plants. Econ 438 Bot 58:5-10. 
$441 \quad$ Figure Legends

442 Fig 1. Location of the three sites sampled along the Chilean coast. Photographs of farmed

443 and natural populations studied are given for each site. All photographs by S. Usandizaga.

444

445 Fig 2. Mean $( \pm \mathrm{SE})$ of the specific growth rate (SGR) of Agarophyton chilensis thalli

446 sampled from farmed and natural populations in Concepción (A and B), Maullín (C and D)

447 and Ancud ( $\mathrm{E}$ and $\mathrm{F}$ ). Thalli were submitted to three temperature treatments (black bars:

$448 \mathrm{~T}=10^{\circ} \mathrm{C}$, light grey bars: $\mathrm{T}=15^{\circ} \mathrm{C}$ and dark grey bars: $\mathrm{T}=20^{\circ} \mathrm{C}$ ). Values are given after 30

449 days of experiment. Different letters denote significant differences between temperature

450 treatments (Tukey's hsd posthoc tests; $p<0.05$; results given independently within each

451 sampling site and temperature treatment).

452 
1 EFFECT OF TEMPERATURE VARIATION IN AGAROPHYTON CHILENSIS:

2 CONTRASTING THE RESPONSE OF NATURAL AND FARMED POPULATIONS

3 Sara Usandizaga

4 Programa de Doctorado en Ciencias, mención Conservación y Manejo de Recursos

5 Naturales, Centro i mar and CeBiB, Universidad de Los Lagos, Camino Chinquihue Km 6,

6 Puerto Montt, Chile

7 Carolina Camus

8 Centro i mar and CeBiB, Universidad de Los Lagos, Camino Chinquihue Km 6, Puerto

9 Montt, Chile

10 José Luis Kappes

11 Centro i mar and CeBiB, Universidad de Los Lagos, Camino Chinquihue Km 6, Puerto

12 Montt, Chile

$13 \quad$ Marie-Laure Guillemin

14 Centro FONDAP de Investigación en Dinámica de Ecosistemas Marinos de Altas Latitudes

15 (IDEAL), Instituto de Ciencias Ambientales y Evolutivas, Facultad de Ciencias,

16 Universidad Austral de Chile, Valdivia, Chile.

17 CNRS, Sorbonne Université, Pontificia Universidad Catolica de Chile, Universidad Austral 18 de Chile, UMI Evolutionary Biology and Ecology of Algae, Station Biologique de Roscoff, 1929680 Roscoff, France.

20 Alejandro H. Buschmann ${ }^{2}$ 
21 Centro i mar and CeBiB, Universidad de Los Lagos, Camino Chinquihue Km 6, Puerto

22 Montt, Chile

$23 \quad{ }^{1}$ Date of submission and acceptance

242 Author for correspondence: Alejandro H. Buschmann, e-mail: abuschma@ulagos.cl, 25 phone: +56652322423

26 Running title: Agarophyton chilensis response to temperature variation

\section{Abstract}

28 During the domestication process, farmers influence the reproduction and care of organisms 29 to ensure a predictable supply of the resource of interest, causing changes in phenotypic 30 and genotypic character frequencies. In Chile, as a result of unconscious selection and 31 domestication process, farmed populations of the red alga Agarophyton chilensis have most 32 likely undergone a reduction in genetic diversity and a modification in life-history traits 33 compared to wild populations. In order to understand the implications that these processes

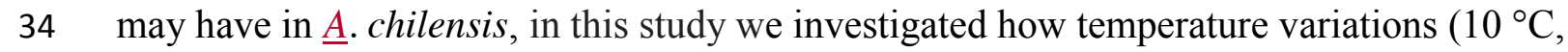
$3515^{\circ} \mathrm{C}$ and $20^{\circ} \mathrm{C}$ ) affect growth and photosynthetic responses of natural and farmed 36 populations from three different localities along the Chilean coast. Natural population's 37 growth decreased at low and high temperature levels while all three farmed populations 38 respond in a very similar way to temperature variation. We propose that a possible outcome 39 of farming, in the A. chilensis vegetatively propagated crops, could have been the selection

40 of general-purpose-genotypes able to perform adequately across the range of temperature

41 tested in our experiment. Furthermore, our results showed that photosynthetic activity was

42 also affected by temperature treatments (e.g., different maximum maximal electron 
43 transport rate and quantum yield values depending on the population type and temperature).

44 In a context of climate change, $\underline{\text { A }}$. chilensis farmed populations may be better able to cope

45 with impacts of anthropogenic activities than natural populations due to the buffer effect of

46 their general-purpose-genotypes, tolerant to a wide range of conditions.

47 Key index words: abiotic factor, domestication, management, general-purpose-genotypes,

48 photosynthesis, origin, seaweed, selection.

49 Abbreviations: ETR $\max _{\text {, }}$ maximal electron transport rate; $F_{v} / F_{m}$, maximal quantum yield; $E k$,

50 irradiance of saturation of ETR; NPQ ${ }_{\max }$, maximal non-photochemical quenching; PAR,

51 photosynthetically active radiation; PSII, photosystem II; RLC, rapid light curves.

\section{Introduction}

53 Domestication is considered a long and complex process during which domesticators

54 influence the reproduction and care of domesticated species to guarantee predictable supply

55 of resources presenting selected traits of interest for human use (Zeder, 2015). This

56 selection process generates changes in phenotypic and genotypic character frequencies of

57 cultivated populations (Zohary, 1984). Even if domestication of marine species is much

58 more recent than the one of terrestrial animals and plants (Duarte et al. 2007), strong

59 evidence for domestication has been found in a few cultivated seaweeds (Valero et al.

60 2017). As for terrestrial plants (Meyer et al. 2012), some domesticated seaweeds are

61 characterized by a shift in their reproductive strategy (e.g., changes from sexual

62 reproduction to vegetative propagation) between natural and farmed populations (Valero et

63 al. 2017). This shift in reproductive strategy has been demonstrated for Agarophyton

64 (referred as Gracilaria in Guillemin et al. 2008) and is probably also present in 
65 Kappaphycus (Ask and Azanza 2002). Asexual propagation enables farmers to selectively

66 multiply superior genotypes and maintain desired phenotypes through vegetative

67 propagation (Valero et al. 2017).

68 In Chile, intensive seaweed farming is limited to the domesticated red alga Agarophyton

69 chilensis used mainly for agar extraction (Buschmann et al. 2017). Even if the

70 domestication process of this species has begun only a few decades ago, the almost

71 complete predominance of diploid individuals in farms demonstrate that farming practices

72 had significantly modified life-history traits as compared to wild populations (Guillemin et

73 al. 2008). Moreover, recent investigations have demonstrated that this red alga colonized

74 the Chilean coast from New Zealand, likely at the end of the Last Glacial Maximum

75 (Guillemin et al. 2014). The lower genetic diversity of the Chilean populations, when

76 compared to the ones from New Zealand, is indeed consistent with a genetic bottleneck

77 resulting from a transpacific range extension and was probably reinforced by the over-

78 exploitation of natural Chilean populations during the 90's (Guillemin et al. 2014). In

79 Chile, active transport and exchange of inoculums of $\underline{A}$. chilensis between coastal

80 communities of fishermen for cultivation purposes have contributed to the artificial

81 expansion of the species distribution. Nowadays, natural populations are distributed

82 between $30^{\circ} \mathrm{S}$ to $45^{\circ} \mathrm{S}$ while farming extends further north, up to Antofagasta, $17^{\circ} \mathrm{S}$ (Bird et

83 al. 1986, Guillemin et al. 2008). Human activities have also leaded to a loss of genotypic

84 diversity in farmed populations that could be partially linked to involuntary selection of

85 faster growing thalli, during the first steps of the domestication process (Guillemin et al.

86 2008, Guillemin et al. 2013, Valero et al. 2017). 
87 Reduced genetic diversity can severely affect the ability of populations to resist pests and

88 pathogens and limit the scope for future genetic improvement in domesticated crops

89 (Robinson et al. 2013). Besides, it has been reported that a reduction in genetic diversity

90 could lead to lower growth and resilience in highly stressful and/or variable environment

91 (Simms 2000). However, to date, few studies have focused on the potential

92 ecophysiological differences between natural and farmed populations of $\underline{A}$. chilensis.

93 Gallegos-Sánchez et al. (2018), detected a significant and negative effect of low salinity

94 conditions on thalli sampled from both natural and farmed $\underline{A}$. chilensis populations but with

95 farmed population's thalli being less affected than the natural ones. Results suggested that

96 farmed populations might be more tolerant to salt stress than wild ones in this species and

97 the authors proposed that this difference between population types could be due to previous

98 selective process carried out by farmers.

99 Considering the possible consequences of unconscious selection (as defined in Zohary

100 2004) and domestication on GAgarophyton- chilensis, we propose that natural populations

101 will be less sensitive to temperature variations than farmed populations. Genotypic

102 diversity has been shown to be higher in natural than farmed $\underline{A}$. chilensis Chilean

103 populations and we propose that the farms will show less effective mechanisms of

104 acclimation (e.g., enhancing of photosynthetic performance) than the one observed in

105 natural populations when confronted with temperature considered as high in their natural

106 environment (i.e., water of the southern coast of Chile do not generally reach $20^{\circ} \mathrm{C}$;

107 Westermeier et al. 1993). The aim of the present study was to assess the effect of

108 temperature on growth and photosynthetic responses of both natural and farmed stands of

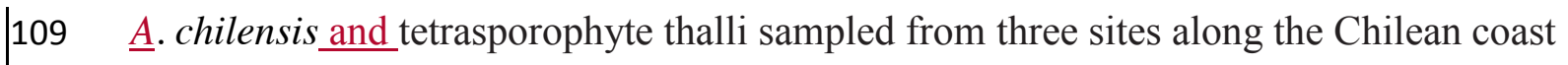


110 were followed during one month in controlled laboratory conditions at $10^{\circ} \mathrm{C}, 15^{\circ} \mathrm{C}$ and $11120^{\circ} \mathrm{C}$.

\section{Materials and methods}

113 Study sites and life cycle phase determination of the sampled thalli

114 A total of 600 individuals were sampled from 3 natural and 3 farmed populations (i.e., 100

115 individuals in each population) during a spring season. One farmed and one natural

116 population were sampled from three sites: Concepción, Maullín and Ancud (Fig.1). The

117 distinction between natural and farmed populations was first based on whether

118 Agarophyton- chilensis thalli were actively planted or not by farmers. As previously

119 reported for the species (Guillemin et al. 2008), thalli were attached to small rocks and

120 pebbles by a holdfast in the three natural $\underline{A}$. chilensis beds while unattached thalli were

121 found embedded in the sandy bottom in the three farmed stands. In each site, natural and

122 farmed populations were separated by $1 \mathrm{~km}$ approximately. In natural beds, individuals

123 sampled correspond to distinct holdfasts (i.e., distinct genotypes produced by sexual

124 reproduction and spore settlement). In farms, to avoid sampling fragments of the same

125 asexually propagated genotype, sampled thalli were separated by at least by $2 \mathrm{~m}$. All the

126 collected thalli were transported in isolated boxes to the CEACIMA hatchery (Centro de

127 Investigación de Acuicultura y Ciencias del Mar, Universidad de Los Lagos) located in the

128 Metri Bay $\left(41^{\circ} 36^{\prime} \mathrm{S}, 72^{\circ} 43^{\prime} \mathrm{W}\right)$. Once in the hatchery, each thallus was cleaned with fresh

129 water and all epiphytes were removed by hand. Thalli were individually marked with a

130 numbered tag and maintained in $400 \_\mathrm{L}$ tanks at $12^{\circ} \mathrm{C}$ with constant aeration, $12 \mathrm{~L}: 12 \mathrm{D}$

131 photoperiod, $20 \mu \mathrm{mol}$ electron $\mathrm{m}^{-2} \mathrm{~s}^{-1}$ photon flux and weekly filtered seawater exchange. 
132 Collected thalli were observed under stereoscope microscope (Stemi DV4, Zeiss, Jena,

133 Germany) to determine phase (i.e., diploid tetrasporophytes or haploid gametophytes) of

134 mature individuals. For vegetative individuals, a 3-cm fragment of tissue was excised from

135 each thallus, placed into plastic bags with silica gel for rapid dehydration. The sex markers

136 available for $\underline{\text { A }}$. chilensis were amplified following Guillemin et al. (2012) and the

137 amplification products were visualized in $1.5 \%$ agarose gel (w/v) after adding $2 \mu 1$ of

138 GelRed ${ }^{\mathrm{TM}}$ (Biotium, Fremont, USA). Results were used to determine sex and phase of

139 vegetative individuals. In order to prevent experimental bias due to ecophysiological

140 variability between life cycle phases (Guillemin et al. 2013), only diploid tetrasporophytes

141 were selected for our experiments.

142 Experimental design

143 The experimental design consisted of 90 2-L Erlenmeyer flasks (i.e., 6 populations of origin

144 of thalli $\times 3$ temperature treatments $\times 5$ replicates per population per temperature treatment)

145 arranged in 15 60-L plastic water tanks fitted with temperature control systems. Three

146 temperature treatments were used: $10^{\circ} \mathrm{C}, 15^{\circ} \mathrm{C}$ and $20^{\circ} \mathrm{C}$. These temperatures were chosen

147 since they roughly represent the temperature range encountered in the field by the study

148 species. Temperature conditions varied widely within sites were $\underline{A}$. chilensis is found and

149 between regions populated by the species along the Chilean coasts with values between 9

$150{ }^{\circ} \mathrm{C}$ and $16{ }^{\circ} \mathrm{C}$ recorded in Maullín (Westermeier et al. 1993) and between $10{ }^{\circ} \mathrm{C}$ and $20^{\circ} \mathrm{C}$

151 in areas further north such as Concepción, Coquimbo and Antofagasta (Santelices and

152 Ugarte 1990). In each 60-L plastic water tanks, one 50W automatic heater (Whale VK-

153 1000, Regent) and one stainless steel thermometer (Hagen, Phelan) were used to maintain

154 constant temperature. For each population under study, five replicates (i.e., five 2-L flasks) 
155 were followed per temperature treatment and eight thalli $(5 \mathrm{~cm}$ length each), selected 156 randomly from distinct tetrasporophytes, were placed in each 2-L flask. Thalli were

157 selected without replacement from a pool of 40 tetrasporophytes, available for each

158 population of origin (see above). Once a week, thalli were transferred to clean 2-L flasks

159 with fresh Provasoli culture media (McLachlan 1973). After one week of acclimation at

$16012^{\circ} \mathrm{C}$, the laboratory experiment was run during 30 days. All Erlenmeyer flasks were under

161 constant conditions of aeration, photoperiod (12 h light: $12 \mathrm{~h}$ dark) and photon flux (20

$162 \mu \mathrm{mol}$ electron $\left.\mathrm{m}^{-2} \mathrm{~s}^{-1}\right)$.

163 Growth

164 Fresh weight of each thallus was assessed weekly on an analytical balance (Sartorius TE

165313 DS, Germany) and the specific growth rate (SGR) was calculated as the percentage of

166 wet weight gain per day according to the formula: $\mathrm{SGR}=\left[\ln \left(\mathrm{Wf} \cdot \mathrm{Wi}^{-1}\right) /(\mathrm{tf}-\mathrm{ti})\right] \times 100$;

167 where $\mathrm{Wi}=$ initial fresh weight, $\mathrm{Wf}=$ final fresh weight, and $\mathrm{t}=$ time (days). Initial fresh

168 weight in the 2-L flasks was of $0.12 \pm 0.06 \mathrm{~g}$, some variation in fresh weight exist between

169 each 2-L flask at the beginning of the experiment since calibration of algal material was

170 based on thallus length (see above).

171 Physiological variables

172 Thallus pieces were collected at the end of the experiment to measure rapid light curves

173 (RLC). As an indicator of quantum efficiency and photoinhibition, we used, $F_{\mathrm{v}} / F_{\mathrm{m}}$, which

174 was determined after incubation of 20 min of the thalli in darkness (Schreiber et al. 1995)

175 with a Junior PAM (Walz GmbH, Effeltrich, Germany). The electron transport rate (ETR,

$176 \mu \mathrm{mol}$ electrons $\cdot \mathrm{m}^{-2} \cdot \mathrm{s}^{-1}$ ) was determined after $20 \mathrm{~s}$ exposure in 12 increasing intensities of 
177 PAR (up to $1500 \mu \mathrm{mol}$ photon $\cdot \mathrm{m}^{-2} \cdot \mathrm{s}^{-1}$ ) provided by a blue light of the Junior PAM device

178 (Schreiber et al. 1995). ETR was calculated according to Schreiber et al. (1995) as follows:

$179 \quad \mathrm{ETR}=\Delta \mathrm{F} / \mathrm{F}^{\prime} \mathrm{m} \cdot E \cdot A \cdot F_{\mathrm{II}}\left(\mu \mathrm{mol}\right.$ electrons $\left.\cdot \mathrm{m}^{-2} \cdot \mathrm{s}^{-1}\right)$

180 Where $\Delta \mathrm{F} / \mathrm{F}^{\prime} \mathrm{m}$ is the effective quantum yield, $E$ is the incident PAR (photosynthetically

181 active radiation) irradiance expressed in $\mu \mathrm{mol}$ photons $\mathrm{m}^{-2} \mathrm{~s}^{-1}, A$ is the thallus absorptance

182 and $F_{\mathrm{II}}$ is the fraction of chlorophyll related to photosystem II (PSII, 400-700m), being 0.15

183 in red seaweed (Grzymski et al. 1997). As an estimator of photosynthetic efficiency, the

184 initial slope of ETR $\left(\alpha_{\mathrm{ETR}}\right)$ and maximum ETR $\left(\mathrm{ETR}_{\max }\right)$ were obtained from the tangential

185 function reported by Eilers and Peeters (1988) and the irradiance saturation $\left(E k_{\mathrm{ETR}}\right)$ was

186 calculated from the intercept between these two parameters. Representing potential thalli

187 photoprotective mechanism, non-photochemical quenching (NPQ) was measured according

188 to Schreiber et al. (1995). The maximal non-photochemical quenching (NPQ $\max )$ was

189 calculated from the tangential function of NPQ versus irradiance function according to

190 Eilers and Peeters (1988).

$191 \quad$ Statistical treatment

192 All analyses were performed in R (3.2.4 version) (Cayuela 2011). Assumptions of

193 homogeneity of variances and normal distribution were tested using Levene`s test and

194 Shapiro-Wilk, respectively. When non-normal residuals and heteroscedasticity were

195 detected, the data were transformed using logarithm (for $E k$ and SGR) or Box-cox (for

$\left.196 F_{\mathrm{v}} / F_{\mathrm{m}}\right)$. The experimental design fitted a three-way ANOVA with treatment (temperature:

$19710^{\circ} \mathrm{C}, 15^{\circ} \mathrm{C}$ and $20^{\circ} \mathrm{C}$ ), site of origin (Concepción, Maullín and Ancud) and population type 
198 (natural or farmed) considered as fixed factors. Statistical differences between groups were 199 analyzed using comparisons of means (Tukey's HSD). Significances were set at $\mathrm{p}<0.05$.

\section{Results}

201 Significant differences were detected in Agarophyton- chilensis specific growth rate (SGR) 202 after 30 days of experimentation between temperature treatments $\left(\mathrm{F}_{(2,72)}=15.46 ; \mathrm{P}<\right.$

$2030.0001)$, between population types $\left(\mathrm{F}_{(1,72)}=4.93 ; \mathrm{P}=0.03\right)$ and a significant interaction was 204 also detected between population type and site of origin $\left(\mathrm{F}_{(2,72)}=5.00 ; \mathrm{P}=0.009\right)$. In

205 Maullín and Ancud, no significant differences between temperature treatments were 206 detected for farmed thalli (Fig.2C and E), while farmed thalli from Concepción showed a 207 slightly but significantly lower SGR at $20^{\circ} \mathrm{C}$ than at $15^{\circ} \mathrm{C}(7.26 \pm 1.48$ and $9.45 \pm 1.92 \mathrm{~g}$. 208 day $^{-1}$, respectively; Fig.2A). In addition, differences among Concepción farmed and natural 209 populations were observed (Tukey test; $\mathrm{P}<0.05$, see Figure $2 \mathrm{~A}$ and $\mathrm{B}$ ). In contrast, SGR 210 was significantly higher at $15^{\circ} \mathrm{C}$ for thalli sampled in natural $\underline{A}$. chilensis stands, whatever 211 the site under study (SGR at $15^{\circ} \mathrm{C}: 7.49 \pm 2.07 \mathrm{~g} \cdot$ day $^{-1}$ in Concepción, $8.81 \pm 2.60 \mathrm{~g} \cdot$ day $^{-}$

$212{ }^{1}$ in Maullín and $8.67 \pm 0.84 \mathrm{~g} \cdot$ day $^{-1}$ in Ancud; Fig. $2 \underline{B}, \mathrm{D}$ and F). Finally, the growth rate 213 did not decrease significantly (Tukey test; $\mathrm{P}<0.05)$ at the lower $\left(10^{\circ} \mathrm{C}\right)$ and the higher $(20$

$214{ }^{\circ} \mathrm{C}$ ) temperature tested for Maullin and Ancud populations (Fig. 2 C, D, E and F).

215 Regarding the photosynthetic responses, significant effect of temperature treatments were 216 detected for all parameters measured: the optimal quantum yield of fluorescence $\left(F_{v} / F_{m,-\mathrm{F}_{(2}}\right.$,

$21735)=13.20 ; \mathrm{P}<0.00001)$, the maximal electron transport rate $\left(\mathrm{ETR}_{\max } ; \mathrm{F}_{(2,35)}=6.17 ; \mathrm{P}=\right.$

$2180.02)$, the saturation irradiance $\left(E k ; \mathrm{F}_{(2,35)}=6.97 ; \mathrm{P}=0.04\right)$-and the maximal non-

219 photochemical quenching $\left(\mathrm{NPQ}_{\max } ; \mathrm{F}_{(2,35)}=6.02 ; \mathrm{P}=0.01\right)$ (see Table 1). Interactions 
220 between temperature treatment and population type were also observed for $\operatorname{ETR}_{\max }\left(\mathrm{F}_{(2,35)}=\right.$

$2219.57 ; \mathrm{P}=0.0005)$ and $E k\left(\mathrm{~F}_{(2,35)}=5.34 ; \mathrm{P}=0.01\right)$ (Table 1). Values of ETR ${ }_{\max }$ and $E k$ were

222 significantly higher for thalli sampled in the farmed population of Concepción and grown at

$223 \quad 20^{\circ} \mathrm{C}$ than for thalli sampled in the farmed population of Ancud and grown at $10^{\circ} \mathrm{C}(18.63$

$224 \pm 12.76$ and $1.44 \pm 0.37 \mu \mathrm{mol}$ electrons $\cdot \mathrm{m}^{-2} \cdot \mathrm{s}^{-1}, 442.97 \pm 306.60$ and $31.86 \pm 4.78 \mu \mathrm{mol}$

225 photons $\cdot \mathrm{m}^{-2} \cdot \mathrm{s}^{-1}$, for ETR $\mathrm{Eax}_{\text {ax }}$ and Ek, respectively; Tukey's HSD tests; $\mathrm{p}<0.05$; Table 2).

226 Significant interactions between temperature treatment, population type and site of origin

227 were observed for $F_{v} / F_{m}\left(\mathrm{~F}_{(4,35)}=2.86 ; \mathrm{P}=0.04\right)$ and $\mathrm{NPQ}_{\max }\left(\mathrm{F}_{(4,34)}=3.31 ; \mathrm{P}=0.02\right)($ Table

228 1). In Maullín at $15^{\circ} \mathrm{C}$, values of $\mathrm{NPQ}_{\max }$ were significantly higher for thalli sampled in the

229 farmed bed than the natural population (Tukey's HSD tests; $\mathrm{p}<0.05$; Table 2).

230 Discussion

231 The present study confirms that natural and farmed Agarophyton chilensis populations

232 respond differentially to temperature variations. Indeed, contrarily to our expectations, our

233 results indicate that farmed populations are less sensitive to temperature variations than

234 natural ones (i.e., thalli growth rate are mostly similar at $10^{\circ} \mathrm{C}, 15^{\circ} \mathrm{C}$ and $20^{\circ} \mathrm{C}$ for farms

235 while thalli from natural populations have a higher growth rate at $15^{\circ} \mathrm{C}$ ). In Chile, farmed

236 population has been under unconscious human selection pressure for, at least, three decades

237 and we propose that a possible outcome could have been the selection of general-purpose-

238 genotypes (as in Baker 1974) in these vegetatively propagated crops. Our results also

239 showed that photosynthetic activity was affected by temperature treatments (e.g., different

240 maximum maximal electron transport rate and quantum yield values depending on the

241 population type and temperature). 
242 Regardless of the origin of the natural population under study, our experiment shows that

243 thalli specific growth rate (SGR) was higher at $15^{\circ} \mathrm{C}$ than at lower (i.e., $10^{\circ} \mathrm{C}$ ) or higher

244 (i.e., $20^{\circ} \mathrm{C}$ ) temperatures. Even if SGR tended to be much more homogeneous for farmed

245 thalli at all temperatures, one slight difference was observed for the farmed thalli from

246 Concepción that show significantly less growth at $20^{\circ} \mathrm{C}$. Supporting our results, a study

247 realized by Santelices and Ugarte (1990) on $\underline{\text { A. chilensis (as Gracilaria chilensis) natural }}$

248 populations from Maullín, also revealed better growth rates at $15^{\circ} \mathrm{C}$ than at $10^{\circ} \mathrm{C}$ or $20^{\circ} \mathrm{C}$.

249 Most temperate species of the genus Agarophyton has been shown to grow faster in

250 temperature ranging between $15^{\circ}$ and $20^{\circ} \mathrm{C}$ (McLachlan and Bird 1984). A study performed

251 in Gracilaria gracilis (as G. verrucosa) reported a slow growth rate at $10^{\circ} \mathrm{C}$ and high

252 mortality after a 14 days' heat-wave in Saldanha Bay, South Africa (Engledow and Bolton

253 1992). A. chilensis, is a temperate-water species with a distribution limited to southern part

254 of the Pacific (Bird et al. 1986, Guillemin et al. 2008) and it is possible that the species

255 present a metabolism with limited temperature tolerance.

256 Although farming has begun only a few decades ago (i.e., during the $\underline{80}$ 's) in Chile, the

257 predominant mechanism for stock propagation by cuttings used in Agarophyton-chilensis

258 farms has already significantly decreased their genotypic diversity when compared with

259 wild populations (Guillemin et al. 2008). There is an overall agreement that genetically

260 more variable populations may be associated with higher resilience, increased productivity

261 and population growth rate as compared with less variable populations (Forsman 2014).

262 However, contrasting with our expectations, farmed thalli in our experiment clearly show a

263 strong ability to grow in contrasting environmental conditions, including the quite

264 "extreme" temperature of $20^{\circ} \mathrm{C}$ tested. In the same way, Gallegos-Sanchez et al. (2018) 
265 concluded that A. chilensis farmed populations may be less sensitive to salt stress and able

266 to grow in a greater range of salinity than natural populations. One possible explanation for

267 these results is that farmed populations of A. chilensis are composed mostly of general-

268 purpose genotypes, able to grow in highly stressful and/or variable environments. General-

269 purpose-genotypes are sometime also referred as 'Jack-of-all-trades, master of none' since

270 they are described as versatile genotypes that are able to perform adequately across a range

271 of environments but are not superior in any of them. These general-purpose-genotypes can

272 confer a species or population a broad tolerance to environmental changes and are often

273 associated with species invasion (Baker 1974, Richards et al. 2006). In Chile, farms have

274 been developed using material growing embedded in muddy estuaries and sandy bays.

275 These habitats are typically highly heterogeneous and present strong seasonal variations in

276 temperature and salinity (Westermeier et al. 1993, Buschmann et al. 1995). It have been

277 demonstrated that intraspecific competition for resources utilization in clonal individuals

278 living in habitats characterized by fluctuating environmental conditions could lead to

279 positive selection of general-purpose-genotypes (Arnaud-Haond et al. 2012).

280 In benthic algae, temperature variations affect photosynthetic metabolism (Davison 1991)

281 determining, for example, seasonal distribution (De Nicola 1996). However, habitats

282 characterized by strong spatial and temporal variations of abiotic factors, request constant

283 adjustment of photosynthetic processes in species populating them (Ensminger et al. 2001).

284 In our study, the highest values of ETR $\max$ and Ek were observed in the A. chilensis farmed

285 population from Concepción grown at $20^{\circ} \mathrm{C}$. These results suggest that the effect of high

286 temperatures on photosynthetic metabolism of this farmed population could be mild.

287 Driven by seasonal changes in river discharge, precipitation, and coastal upwelling, high

288 variability in abiotic conditions (e.g., temperature, salinity and turbidity; Saldías et al. 
289 2016) has been observed in the river mouths were A. chilensis thalli are planted in

290 Concepción. These characteristics could be associated to distinctive heat susceptibility of

291 the photosynthetic metabolism of the A. chilensis thalli growing in Concepción farms. In

292 our experiment, the response of the maximum quantum yield $\left(F_{\mathrm{v}} / F_{\mathrm{m}}\right)$ to temperature was

293 quite variable. The lowest value of $F_{\mathrm{v}} / F_{\mathrm{m}}$ (indicating photoinhibition) was observed at

294 intermediate temperature $\left(15^{\circ} \mathrm{C}\right)$ in the farm of Maullín. In plants, it is well known that

295 limitation of electron transport that reduces the ability of plants to use light result in an

296 excess light energy that may cause photoinhibition due to damage to the PSII apparatus

297 (Moll and Steinback 1986). However, short-term response of photosynthesis to temperature

298 cannot easily be used to infer the long-term response of algal growth (Wienke and Dieck

299 1989). Indeed, despite the possible signal of photoinhibition detected at $15^{\circ} \mathrm{C}$, no limited

300 growth could be observed in these Agarophyton-chilensis thalli.

301 Populations of Agarophyton: chilensis from different sites in Chile have been reported to

302 present ecological differences, potentially linked to local adaptation in response to specific

303 abiotic and biotic environmental characteristics (Santelices and Ugarte 1990, Usandizaga et

304 al. 2018). The success of Agarophyton farming depends in part on the origin of the initial

305 inoculum since differences in thallus morphology, agar yield and gel strength and

306 susceptibility to epiphytes exist among regions and populations. Indeed, it have been

307 suggested that random transplantation between distinct habitats could lead to cultivation

308 failure (Santelices and Ugarte 1990). However, in our experiment, even if we included

309 sampling sites located more than $700 \mathrm{~km}$ apart, no major effect of the site of origin were

310 detected on growth or photosynthesis. A possible explanation for this discrepancy is that

311 continuous transplantations and exchanges during the last decades have leaded to the

312 homogenization of the genetic diversity among the whole Chilean coast. However, this 
313 hypothesis is not in accordance with population genetic studies showing the presence of

314 clear genetic divergence between regions in Chile (Guillemin et al. 2008 and 2014). Studies

315 focused on the effect of other stressors (e.g., nutrient supply, salinity, irradiance) and the

316 cumulative effects of various of these stressors on the physiological responses of distinct

317 genotypes is now needed in order to better explore the resistance of $\underline{A}$. chilensis populations

318 to stress.

320 Conclusion

321 Agarophyton chilensis tolerance of a wide range of abiotic conditions has been proposed as

322 one of the main reasons of the species successful expansion in the Pacific and establishment

323 in a wide array of habitats (Santelices and Ugarte 1990, Chow et al. 2001). These

324 successful extension waves have probably also been facilitated by intrinsic characteristics

325 of the species, such as its capacity to shift between sexual and asexual reproduction

326 (Guillemin et al. 2014). We suggest that the possible selection for general-purpose-

327 genotypes in the asexually reproducing farmed populations may help modulating the

328 impact of environmental variation on population dynamics (Reed et al. 2010) and Chilean

329 Agarophyton crop to better cope with impacts of climate change and direct anthropogenic

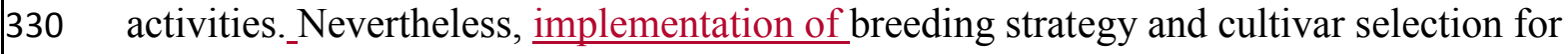

331 mariculture systems improvement has not yet begun in Chile and development of long-term

332 management plans for the sustainable exploitation of A. chilensis populations is dearly

333 needed.

334 Acknowledgements

335 This research was supported by a doctoral fellow from Universidad de Los Lagos 

and $\mathrm{N}^{\circ} 1170541$ (CONICYT) to AHB and MLG, respectively. Additional support was provided by the grant "Término de Tesis" awarded by Universidad de Los Lagos. The

339 authors are grateful for the help in the field of R. Altamirano and S. V. Pereda for the 340 revision of this manuscript. We also wish to thank two anonymous referees who greatly

341 improved the manuscript with constructive suggestions. The authors declare no conflict

342 of interest.

\section{References}

346 Arnaud-Haond S, Duarte C, Diaz-Almela E, Marbà N, Sintes T, Serrão (2012) Implications

347 of extreme life span in clonal organisms: millenary clones in meadows of the threatened 348 seagrass Posidonia oceanica. PloS one 7:e30454.

349 Ask EI, Azanza RV (2002) Advances in cultivation technology of commercial

350 eucheumatoid species: a review with suggestions for future research. Aquaculture 206:257351277.

352 Baker HG (1974) The evolution of weeds. Annu Rev Ecol Syst 5:1-24.

353 Bird CJ, McLachan J, Oliveira EC (1986) Gracilaria chilensis sp. nov; (Rhodophyta,

354 Gigartinales), from Pacific South America. Can J Bot 64:2928-2934.

355 Bradshaw AD(1965) Evolutionary significance of phenotypic plasticity in plants. Adv Genet $356 \quad 13: 115-155$.

357 Buschmann AH, Correa JA, Westermeier R, Hernandez-Gonzalez MDC, Norambuena R 358 (2001) Red algal farming in Chile: a review. Aquaculture 194:203-220. 
359 Buschmann AH, Westermeier R, Retamales C (1995) Cultivation of Gracilaria in the sea-

360 bottom in southern Chile: a review. J Appl Phycol 7:291-301.

361 Buschmann AH, Camus C, Infante J, Neori A, Israel A, Hernández-González MC, Pereda

362 SV, Gomez-Pinchetti JL, Golberg A, Tadmor-Shalex N, Critchley AT (2017) Seaweed

363 production: overview of the global state of exploitation, farming and emerging research

364 activity. Eur J Phycol 52:391-406.

365 Cayuela L (2011) Modelos lineales: Regresión, ANOVA y ANCOVA. Universidad Rey

366 Juan Carlos, Madrid.

367 Chow FY, Macchiavello J, Cruz SS, Fonck E, Olivares J (2001) Utilization of Gracilaria

368 chilensis (Rhodophyta: Gracilariaceae) as a biofilter in the depuration of effluents from

369 tank cultures of fish, oysters, and sea urchins. J World Aquac Soc 32:215-220.

370 Davison IR (1991) Environmental effects on algal photosynthesis: temperature. J Phycol

$371 \quad 27: 2-8$.

372 De Nicola DM (1996) Periphyton responses to temperature at different ecological levels.

373 In: Stevenson RJ, Bothwell ML, Lowe RL (eds) Algal ecology: freshwater benthic

374 ecosystems. Academic Press, San Diego, pp 149-181.

375 Duarte CM, Marbá N, Holmer M (2007) Rapid domestication of marine species. Science $376 \quad 316: 382$

377 Eilers PHC, Peeters JCH (1988) A model for the relationship between light intensity and 378 the rate of photosynthesis in phytoplankton. Ecol Model 42:199-215.

379 Engel CR, Aberg P, Gaggiotti O, Destombe C, Valero M (2001) Population dynamies and 380 stage structure in a red haploid-diploid red seaweed, Gracilaria gracilis. J Ecol 89:436-

381450. 
382 Engledow HR, Bolton JJ (1992) Environmental tolerances in culture and agar content of

383 Gracilaria verrucosa (Hudson) Papenfuss (Rhodophyta, Gigartinales) from Saldanha Bay. 384 S Afr J Bot 58:263-267.

385 Ensminger I, Xyländer M, Hagen C, Braune W (2001) Strategies providing success in a 386 variable habitat: III. Dynamic control of photosynthesis in Cladophora glomerata. Plant 387 Cell Environ 24:769-779.

388 Forsman A (2014) Rethinking phenotypic plasticity and its consequences for individuals, 389 populations and species. Heredity 115:1-9.

390 Gallegos-Sánchez CF, Beltrán J, Flores V, González AV, Santelices B (2018) Testing the 391 effects of heterozygosity on growth rate plasticity in the seaweed Gracilaria chilensis 392 (Rhodophyta). Ecol Evol 8:5741-5751.

393 Grzymski J, Johnsen G, Sakshug E (1997) The significance of intracellular self-shading on 394 the bio-optical properties of brown, red and green macroalgae. J Phycol 33:408-414.

395 Guillemin M-L, Faugeron S, Destombe C, Viard F, Correa JA, Valero M (2008) Genetic

396 variation in wild and cultivated population the haploid-diploid red alga Gracilaria

397 chilensis: how farming practices favour asexual reproduction and heterozygosity. Evolution $398 \quad 62: 1500-1519$.

399 Guillemin M-L, Huanel OR, Martínez EA (2012) Characterization of genetic markers 400 linked to sex determination in the haploid-diploid red alga Gracilaria chilensis. J Phycol $401 \quad 48: 365-372$.

402 Guillemin M-L, Sepúlveda RD, Correa, JA, Destombe C (2013) Differential ecological 403 responses to environmental stress in the life history phases of the isomorphic red alga 
405 Guillemin M-L, Valenzuela P, Gaitán-Espitia JD, Destombe C (2014) Evidence of

406 reproductive cost in the triphasic life history of the red alga Gracilaria chilensis

407 (Gracilariales, Rhodophyta). J Appl Phycol 26:569-575.

408 Kim JK, Yarish C, Hwang EK, Park M, Kim Y (2017) Seaweed aquaculture: cultivation

409 technologies, challenges and its ecosystem services. Algae 32:1-13.

410 Krueger-Hadfield SA, Kollars NM, Byers JE, Greig TW, Hammann M, Murray DC,

411 Murren CJ, Strand AE, Terada R, Weinberger F, Sotka EE (2016a) Invasion of novel

412 habitats uncouples haplo-diplontic life cycles. Mol Ecol 25:3801-3816.

413 Krueger-Hadfield, SA, Carmona GH, Terada R, López-Vivas JM, Riosmena-Rodríguez R

414 (2016b) New Record of the non-Native Seaweed Gracilaria parvispora in Baja California-

415 A Note on Vergara-Rodarte et al. (2016). Cryptogam Algol 37:257-263.

416 Krueger-Hadfield, SA, Magill CL, Bunker F St PD, Mieszkowska N, Sotka EE, Maggs CA

417 (2017) When invaders go unnoticed: The case of Gracilaria vermiculophylla in the British

418 Isles. Cryptogam Algol 38:379-400.

419 Eynch M (1984) Destabilizing hybridization, general-purpose genotypes and geographic

420 parthenogenesis. Quart Rev Biol 59:257-290.

421 McLachlan J (1973) Growth media-marine. In: Stein JR (ed) Handbook of Phycological

422 Methods. Cambridge University Press, Cambridge, pp 25-52.

423 McLachlan J, Bird CJ (1984) Geographical and experimental assessment of the distribution

424 of species of Gracilaria in relation to temperature. Helgolander Meeresun 38:319-334. 
425 Meyer RS, Duval AE, Jensen HR (2012) Patterns and processes in crop domestication: an

426 historical review and quantitative analysis of 203 global food crops. New Phytol 196:29-48.

427 Miner BG, Sultan SE, Morgan SG, Padilla DK, Relyea RA (2005) Ecological

428 eonsequences of phenotypic plasticity. Trends Ecol Evol 20:685-692.

429 Mitton JB, Grant MC (1984) Associations among protein heterozygesity, growth rate, and

430 developmental homeostasis. Annu Rev Ecol Syst 15:479-499.

431 Moll BA, Steinback KE (1986) Chilling sensitivity in Oryza sativa: the role of protein

432 phosphorylation in protection against photounhibition. Plant Physiol 80:420-423.

433 Necchi OJ (2006) Short-term responses of photosynthesis to temperature and irradiance in

434 the freshwater red alga Compsopogon coeruleus. Algol Stud 119:125-138.

435 Reed TE, Waples RS, Schindler DE, Hard JJ, Kinnison MT (2010) Phenotypic plasticity

436 and population viability: the importance of environmental predictability. Proc R Soc B

$437 \quad 277: 3391-3400$.

438 Richards CL, Bossdorf O, Muth NZ, Gurevitch J, Pigliucci M (2006) Jack of all trades,

439 master of some? On the role of phenotypic plasticity in plant invasions. Ecol Lett 9:981-

440993.

441 Robinson N, Winberg P, Kirkendale L (2013) Genetic improvement of macroalgae: status

442 to date and needs for the future. J. Appl Phycol 25:703-716.

443 Saldías GS, Largier JL, Mendes R, Pérez-Santos I, Vargas CA, Sobarzo M (2016) Satellite-

444 measured interannual variability of turbid river plumes off central-southern Chile: spatial

445 patterns and the influence of climate variability. Prog Oceanogr 146:212-222.

446 Santelices B, Doty MS (1989) A review of Gracilaria farming. Aquaculture 78:95-133. 
447 Santelices B, Ugarte R (1990) Ecological differences among Chilean population of 448 commercial Gracilaria. J Appl Phycol 2:17-26.

449 Schmalhausen I (1949) Factors of evolution. Blakiston Press, New York, pp 326.

450 Schreiber U, Endo T, Mi H, Asada K (1995) Quenching analysis of chlorophyll

451 fluorescence by the saturation pulse method: particular aspects relating to the study of

452 eukaryotic algae and cyanobacteria. Plant Cell Physiol 36:873-882.

453 Simms EL (2000) Defining tolerance as a norm of reaction. Evol Ecol 14:563-570.

454 Usandizaga S, Camus C, Kappes JL, Guillemin M-L, Buschmann AH (2018) Nutrients, but 455 not genetic diversity, affect Gracilaria chilensis (Rhodophyta) farming productivity and 456 physiological responses. J Phycol 54:860-869-https://doi:10.1111/jpy.12785.

457 Valero M, Guillemin M-L, Destombe C, Jacquemin B, Gachon C, Badis Y, Buschmann 458 AH, Camus C, Faugeron S (2017) Perspectives on domestication research for sustainable 459 seaweed aquaculture. Perspect Phycol 4:33-46.

460 Via S, Gomullkiewiez R, De Jong G, Scheiner S, Schlichting CD, Tienderen PV (1995)

461 Adaptative phenotypic plasticity-consensus and controversy. Trends Ecol Evol 10:212 217.

462 Westermeier R, Gómez I, Rivera P (1993) Suspended farming of Gracilaria chilensis

463 (Rhodophyta, Gigartinales) at Cariquilda river, Maullín, Chile. Aquaculture 113:215-229.

464 Wienke C, Dieck I (1989) Temperature requirements for growth and temperature tolerance 465 of macroalgae endemic to the Antarctic region. Mar Ecol Prog Ser 54:189-197. 
466 Zeder MA (2015) Core questions in domestication research. P Natl Acad Sci 11:31914673198.

468 Zohary D (1984) Modes of evolution in plants under domestication. In: Grant W F (ed)

469 Plant Biosystematics. Academic Press Canada, Montreal, pp 579-586.

470 Zohary D (2004) Unconscious selection and the evolution of domesticated plants. Econ

$471 \quad$ Bot 58:5-10.

472

473 
$474 \quad$ Figure legends

475 Fig 1. Location of the three sites sampled along the Chilean coast. Photographs of farmed

476 and natural populations studied are given for each site. All photographs by S. Usandizaga.

477

478 Fig 2. Mean $( \pm \mathrm{SE})$ of the specific growth rate (SGR) of Agarophyton chilensis thalli

479 sampled from farmed and natural populations in Concepción (A and B), Maullín ( $\underline{\mathrm{C} \text { and } \mathrm{D})}$

480 and Ancud (E and F). Thalli were submitted to three temperature treatments (black bars:

$481 \mathrm{~T}=10^{\circ} \mathrm{C}$, light grey bars: $\mathrm{T}=15^{\circ} \mathrm{C}$ and dark grey bars: $\mathrm{T}=20^{\circ} \mathrm{C}$ ). Values are given after 30

482 days of experiment. Different letters denote significant differences between temperature

483 treatments (Tukey's hsd posthoc tests; $p<0.05$; results given independently within each

484 sampling site and temperature treatment). 

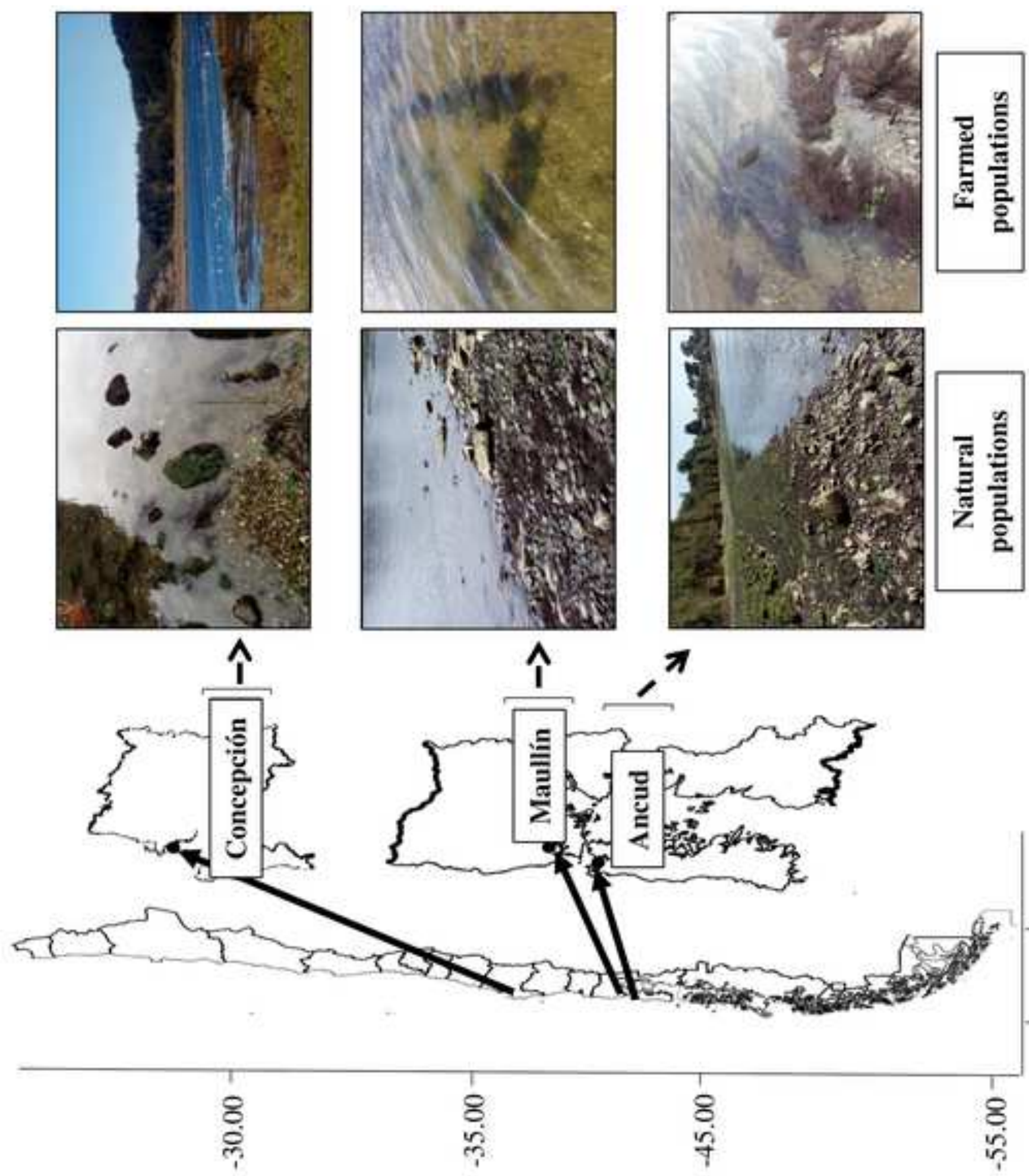

$\hat{\imath}$
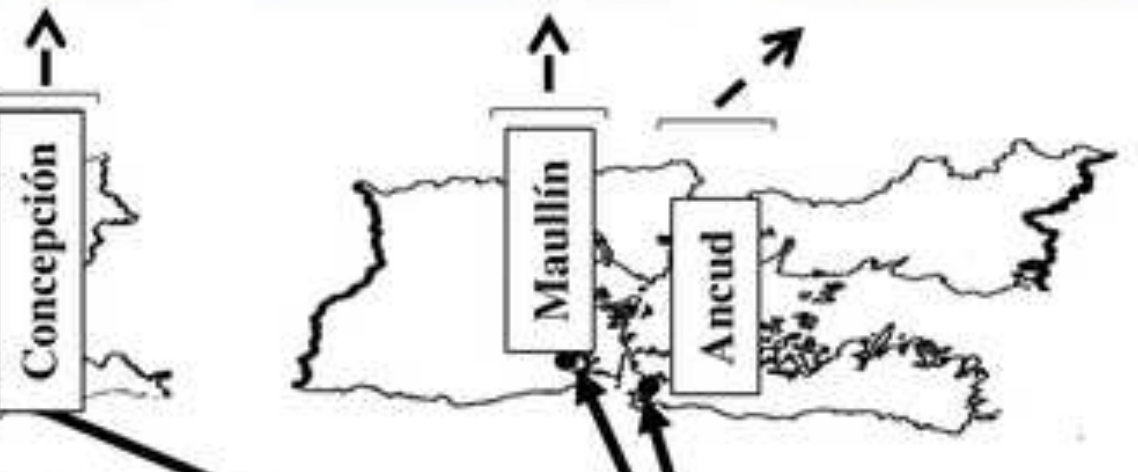

8
$-\frac{8}{9}$
-8
$-\frac{5}{7}$ 
Click here to access/download;line figure;Fig. 2A, B, C, D, E, F.TIF
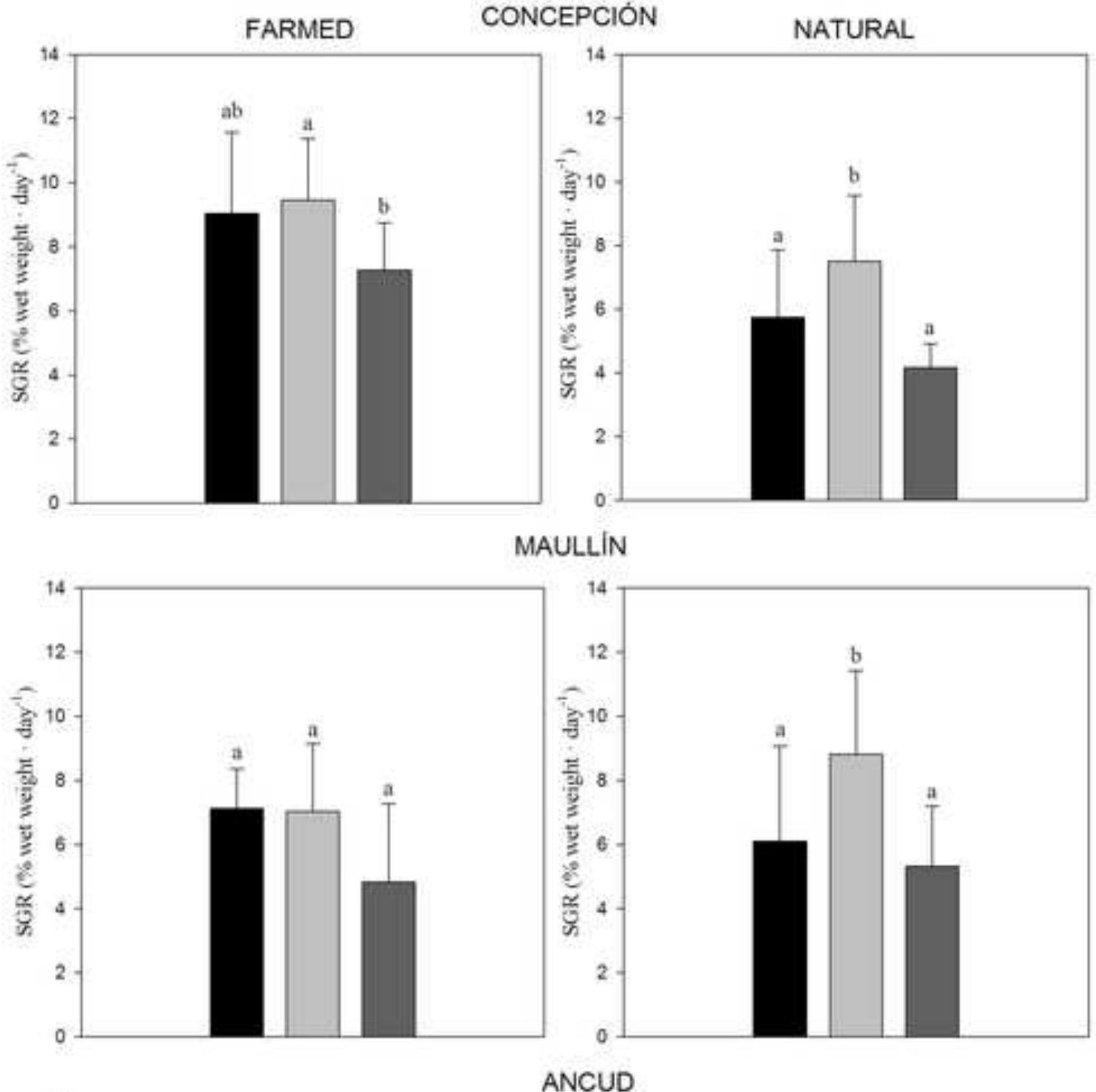

ANCUD
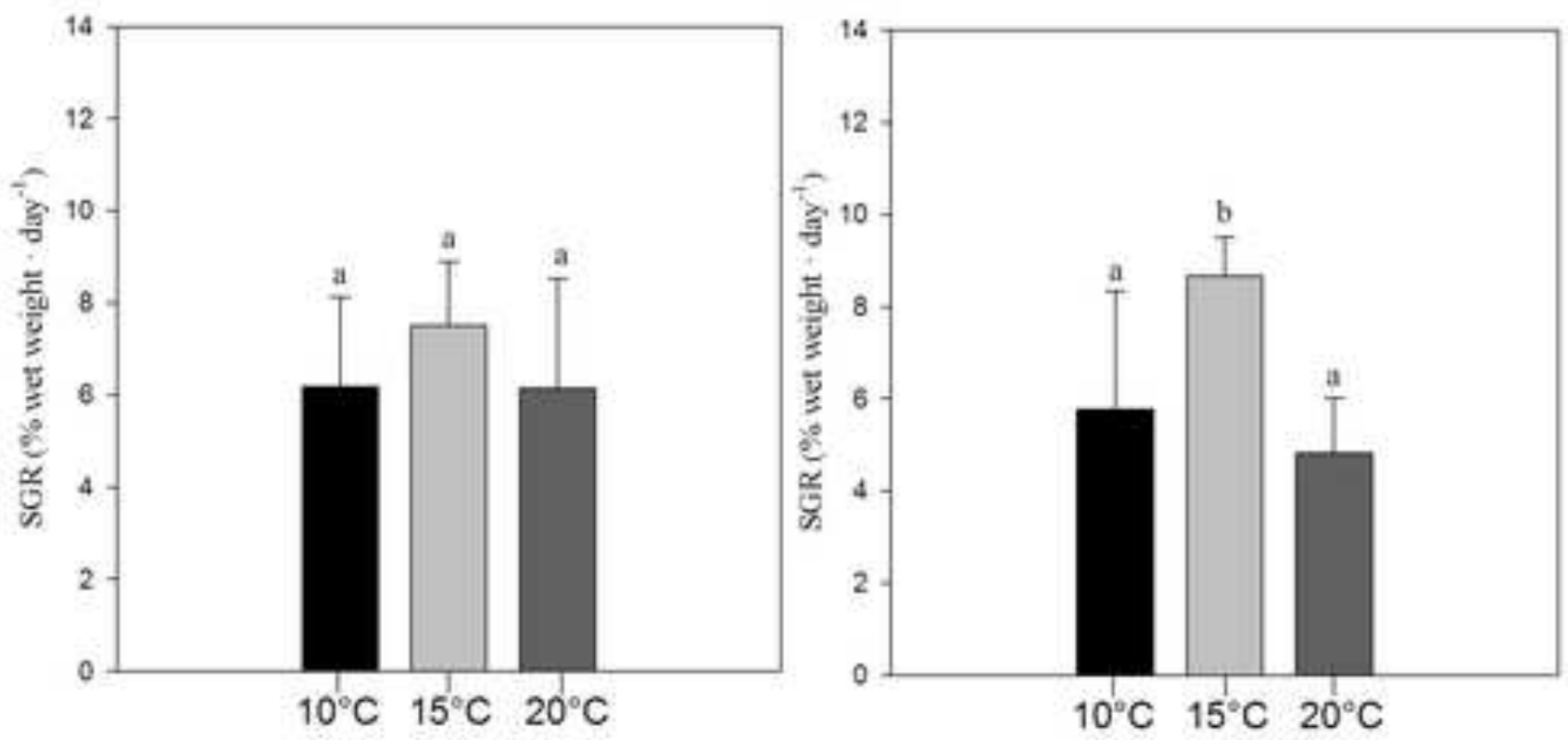


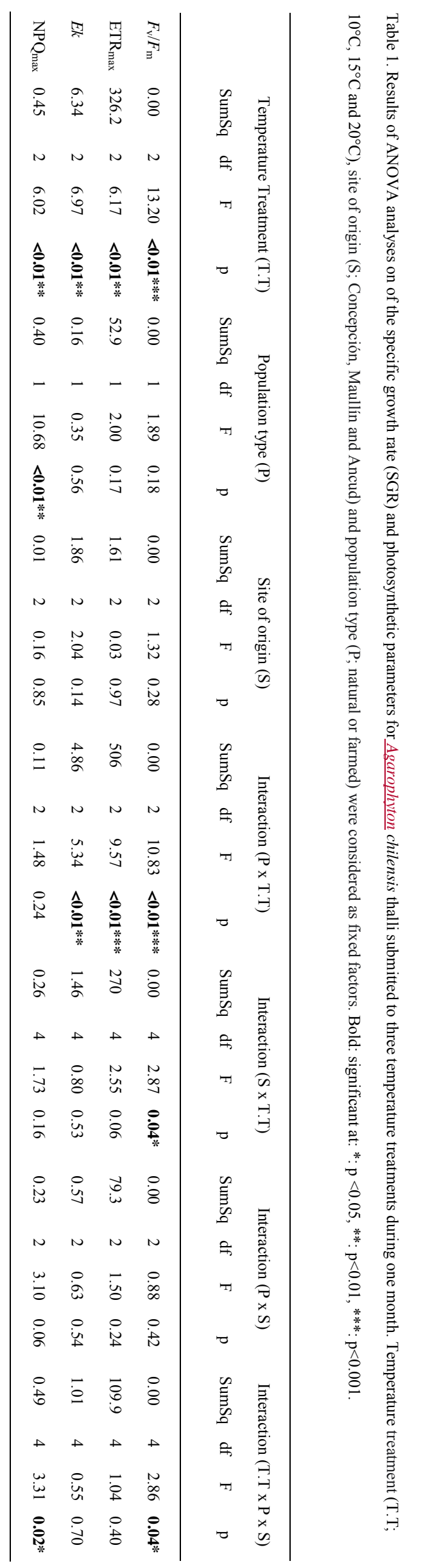




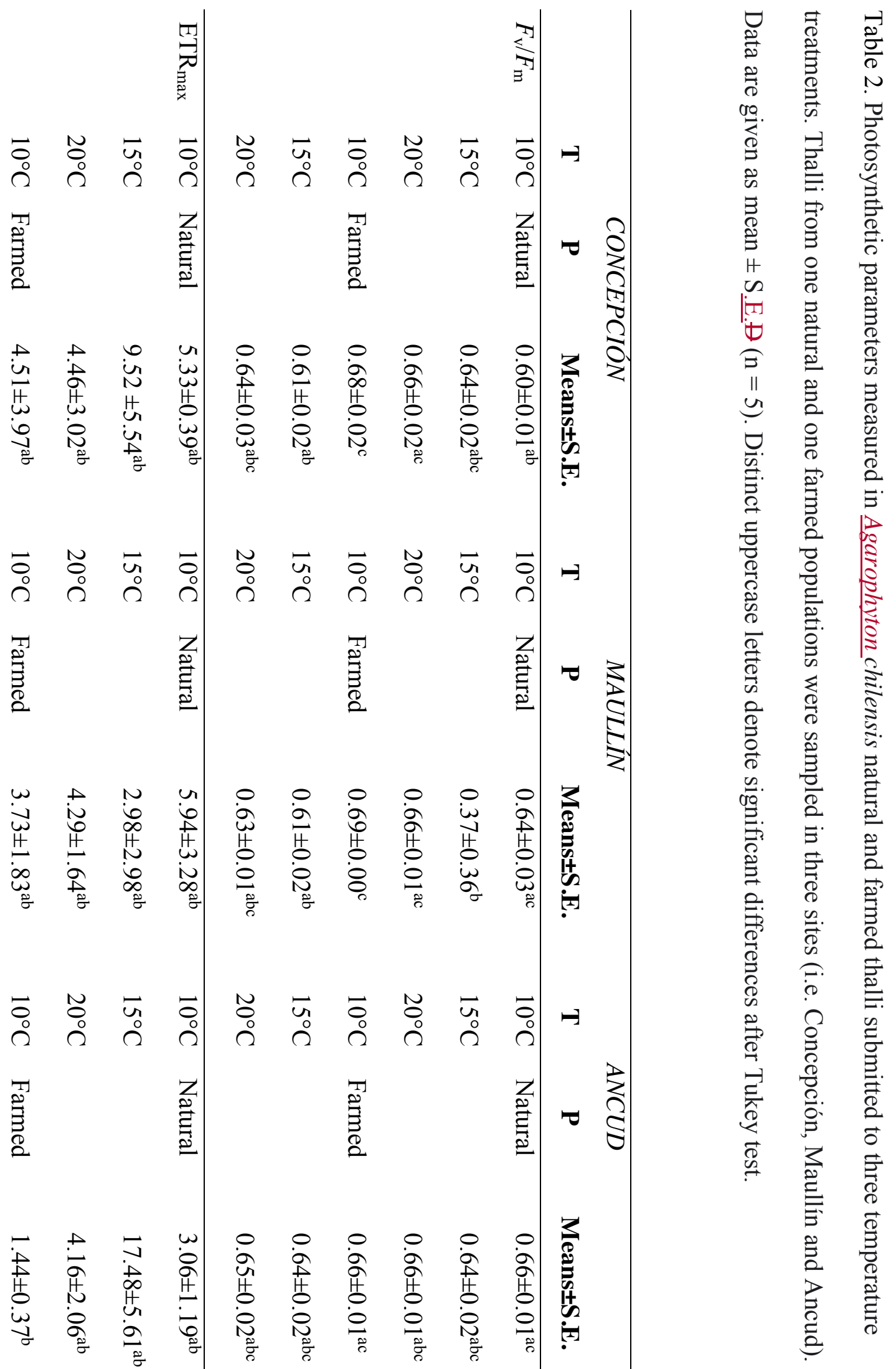




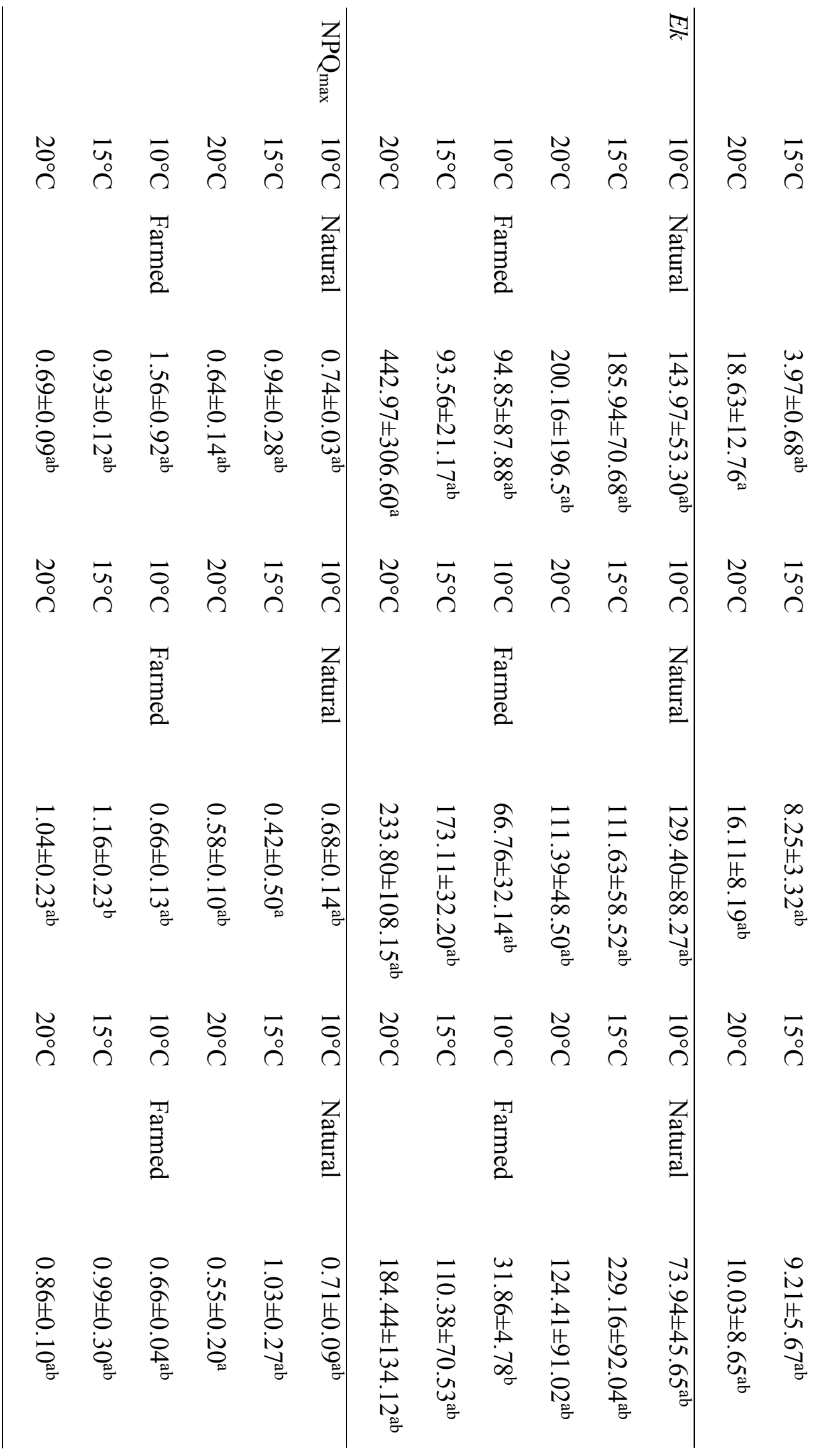

